Volume 120

Issue 1 Dickinson Law Review - Volume 120,

2015-2016

6-1-2015

\title{
Knowledge, Recklessness and the Connection Requirement Between Actus Reus and Mens Rea
}

Alexander F. Sarch

Follow this and additional works at: https://ideas.dickinsonlaw.psu.edu/dlra

\section{Recommended Citation}

Alexander F. Sarch, Knowledge, Recklessness and the Connection Requirement Between Actus Reus and Mens Rea, 120 DICK. L. REV. 1 (2015).

Available at: https://ideas.dickinsonlaw.psu.edu/dlra/vol120/iss1/2

This Article is brought to you for free and open access by the Law Reviews at Dickinson Law IDEAS. It has been accepted for inclusion in Dickinson Law Review by an authorized editor of Dickinson Law IDEAS. For more information, please contact lja10@psu.edu. 


\title{
Article
}

\section{Knowledge, Recklessness and the Connection Requirement Between Actus Reus and Mens Rea}

\author{
Alexander F. Sarch*
}

\begin{abstract}
It is a foundational, but underappreciated principle of criminal liability that being guilty of a crime requires not only possessing the requisite mens rea and actus reus, but also that this mens rea be appropriately connected to the actus reus. That is, the former must "concur with" or "actuate" the latter. While there has been substantial discussion of the connection requirement as applied to the mens rea of intent, the meaning of this requirement as applied to knowledge and recklessness has received far less attention. In this Article, I consider one of the few sophisticated attempts to spell out the connection requirement as applied to knowledge and recklessness crimes-namely, the counterfactual approach offered by Ken Simons. However, I argue that this sort of approach faces serious problems. In its place, I defend a different kind of approach to the connection requirement one that does

* Postdoctoral Fellow, Center for Law and Philosophy, University of Southern California. The author would like to thank Erik Encarnacion, Andrei Marmor, Jon Quong, Steven Schaus, Ken Simons, Will Thomas and Gideon Yaffe for helpful comments and conversations about earlier drafts of this paper.
\end{abstract}


not rely on counterfactual tests, but rather places normative questions front and center.

\section{Table of Contents}

INTRODUCTION

I.THE CONNECTION REQUIREMENT GENERALLY AND THE SPECIAL

DIFFICULTY CONCERNING KNOWLEDGE AND RECKLESSNESS...................7

A. General Features of the Connection Requirement............................... 7

B. Why the Requirement Is Trickier for Knowledge and

Recklessness: Desideratum 1 .12

II.FURTHER DIFFICULTIES WITH THE CONNECTION REQUIREMENT FOR

KNOWLEDGE AND RECKLESSNESS: LATENT KNOWLEDGE OR RISK-

AWARENESS

A. Clarifying Knowledge and Recklessness ......................................16

B. How Knowledge and Recklessness Can Be Actually Present

During the Actus Reus but Remain Unexpressed ...........................17

C. A Worry: When Is Latent Knowledge Really Knowledge? ..............20

D. Desideratum 2: How to Sort Cases of Latent Knowledge?...............24

III.SIMONS' COUNTERFACTUAL ACCOUNT OF THE CONNECTION

REQUIREMENT FOR KNOWLEDGE AND RECKLESSNESS..........................26

A. Simons' Account .................................................................27

B. An Initial Problem ...................................................................29

C. The Problem with $\mathrm{CRAC}_{\mathrm{K}}$ as a Culpability Test.............................30

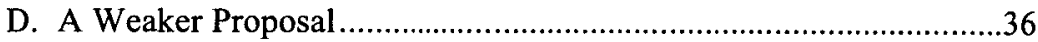

IV.A NON-COUNTERFACTUAL ACCOUNT OF THE CONNECTION

REQUIREMENT FOR KNOWLEDGE AND RECKLESSNESS ..........................39

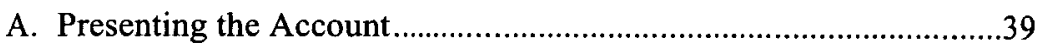

B. Extending the Account to Recklessness .........................................49

C. Concluding Remarks ...................................................................50

\section{INTRODUCTION}

William J. Jackson was supposed to show up in court, but didn't.' He faced charges of driving with a suspended license, and although two court dates had been set in advance of his upcoming trial, he missed them both. $^{2}$ At his subsequent trial for the crime of knowingly failing to appear in court, Jackson claimed he had made an honest mistake about the first court date, and then assumed he would be notified when the

1. Jackson v. State, 85 P.3d 1042 (Alaska Ct. App. 2004).

2. Id. 
second court date was rescheduled. ${ }^{3}$ The jury didn't believe him, and he was convicted. ${ }^{4}$

On appeal, Jackson argued that the trial court had erred in rejecting his requested jury instructions. ${ }^{5}$ He had asked that the jury be instructed that he "not be found guilty unless the State proved that, on the very dates that Jackson was scheduled to appear in court... Jackson consciously considered his obligation to appear in court and decided to ignore it." Jackson argued that the trial court had erred in declining to give these instructions because it amounted to abandoning the requirement of "finding a 'concurrence of ... guilty act and ... guilty mind." "7

Jackson's litigation strategy in this case relied on a foundational, but often underappreciated, principle of criminal liability, according to which conviction of a crime requires not only possessing the requisite mens rea and actus reus, but also that this mens rea be appropriately connected to the actus reus. ${ }^{8}$ As Ken Simons puts it, "the culpable state of mind must 'concur' with the act causing the harm in time, and in the right way." What is more, it is generally agreed that the required connection between mens rea and actus reus involves some form of temporal concurrence. ${ }^{10}$ Accordingly, Jackson's attorney must have reasoned that the requisite temporal concurrence between mens rea and actus reus cannot have existed unless Jackson consciously attended to his knowledge of his

3. Id.

4. Id. at 1044 .

5. Id. at 1043 .

6. Id. (emphasis added).

7. Id.

8. See 1 Wayne LaFave, Substantive Criminal Law $\S 6.3$ (2d ed. 2014) ("With those crimes which require some mental fault (whether intention, knowledge, recklessness, or negligence) in addition to an act or omission, it is a basic premise of Anglo-American criminal law that the physical conduct and the state of mind must concur."); JOSHUA DRESSleR, UNDERSTANDING CRIMINAL LAW 199 (5th ed. 2009) (observing that the "principle of concurrence contains two components:" first, "the defendant must possess the requisite mens rea at the same moment" as the actus reus, and second, "[t]he defendant's conduct that caused the social harm must have been set into motion or impelled by the thought process that constituted the mens rea of the offense"); see also Morissette v. United States, 342 U.S. 246, 251 (1952) (describing crime "as a compound concept, generally constituted only from concurrence of an evil-meaning mind with an evil-doing hand"). The connection requirement has also been codified in some states' criminal codes. See, e.g., Cal. Penal Code $\S 20$ (2014) ("In every crime or public offense there must exist a union, or joint operation of act and intent, or criminal negligence.").

9. Kenneth W. Simons, Does Punishment for "Culpable Indifference" Simply Punish for "Bad Character"? Examining the Requisite Connection Between Mens Rea and Actus Reus, 6 BUFF. CRIM. L. REV. 219, 231-32 (2002).

10. LAFAVE, supra note 8 (noting that "it is sometimes assumed that there cannot be such concurrence unless the mental and physical aspects exist at precisely the same moment of time," though observing that this is not sufficient for the requirement to be satisfied). See also DRESSLER, supra note 8 at 199-200. 
obligation to appear in court at the same time as he performed the actus reus of the crime charged (i.e., did something other than appearing in court on the day he was supposed to be there).

The Court of Appeals, however, rightly rejected Jackson's argument. ${ }^{11} \mathrm{He}$ had misunderstood the nature of the connection requirement-sometimes also called the requirement of a "union," "joint operation," or "concurrence" between mens rea and actus reus. ${ }^{12}$ As the court explained, this requirement is satisfied only if "the defendant's culpable mental state actuates the prohibited conduct, even though there may not be strict simultaneity between the two."13 The court reasoned that Jackson's awareness of his obligation to appear in court on the relevant day might well have been involved in actuating his failure to appear, even though this awareness only occurred well before the date on which he was due in court. For example, the court noted, "Jackson would be guilty of 'knowingly' failing to appear if he decided early on that he would not attend his scheduled court appearances, and he then dismissed the matter from his mind." ${ }^{14}$ Accordingly, the court affirmed Jackson's conviction for misdemeanor failure to appear. ${ }^{15}$

Although the Jackson decision appears sound, it nonetheless raises a number of difficult questions about the connection requirement. First, what does it mean for a particular piece of knowledge to be involved in actuating one's conduct? It is relatively clear what it takes for the

11. Jackson, 85 P.3d at 1043-44.

12. See, e.g., Cal. Penal Code $\S 20$ (2014) ("In every crime or public offense there must exist a union, or joint operation of act and intent, or criminal negligence."); Jenkins v. State, 877 P.2d 1063, 1065 (Nev. 1994) ("To constitute crime there must be unity of act and intent. In every crime or public offense there must exist a union, or joint operation of act and intention, or criminal negligence."); State v. Sunday, No. 39169, 2013 WL 5329290, at *3-4 (Idaho Ct. App. Sept. 24, 2013) (holding that the challenged jury instructions "adequately instructed the jury that a union or joint operation of act and intent existed"); People v. Marcy, 628 P.2d 69, 73 (Colo. 1981) ("In order to subject a person to criminal liability for his conduct, there generally must be a concurrence of an unlawful act (actus reus) and a culpable mental state (mens rea ).").

13. Jackson, 85 P.3d at 1043 (emphasis added). See also LAFAVE, supra note 8 (noting that the connection requirement is satisfied "when the defendant's mental state actuates the physical conduct") (emphasis added); DRESSLER supra note 8, at 199 (observing that "[ $t]$ he defendant's conduct that caused the social harm must have been set into motion or impelled by the thought process that constituted the mens rea of the offense") (emphasis added).

14. Jackson, 85 P.3d at 1043.

15. Id. at 1043-44. 
intention to bring about $\mathrm{p}$ to actuate a given action, $\mathrm{A} .{ }^{16}$ Roughly put, it requires that one have an intention to bring about $p$, and this intention (non-deviantly) causes one to do A, such that we can plausibly say A was done in order to bring about . $^{17}$ But what of knowledge? When one acts while merely knowing that $\mathrm{p}$, it usually will not be the case that one acts as one does in order to bring about $p$. So what connection must there be between the actus reus and the relevant piece of knowledge in order for me to be blamed or punished for acting with this knowledge? If, as Jackson suggests, it is not merely a matter of consciously possessing the knowledge at the time one acts, then what is required?

Second, and perhaps more difficult, how does the connection requirement apply to cases involving the familiar phenomenon of latent or otherwise merely dispositional knowledge? ${ }^{18}$ Recall the Jackson court's dictum that Jackson would have been guilty of knowingly failing to appear "if he decided early on that he would not attend his scheduled court appearances, and he then dismissed the matter from his mind."19 Even if, on the day in question, he was not consciously attending to the fact that he needed to be in court (i.e. his knowledge of his obligation to appear in court was merely latent or dispositional), the connection requirement still plausibly would be satisfied. But in other cases of latent knowledge, it seems the requirement might not be satisfied. Suppose that in the days leading up to the appointed court dates, Jackson had been well aware of his obligation to appear in court, but then on the day of his first appearance, he received some shocking news or had a traumatic experience that prevented him from attending to his knowledge of needing to be in court, i.e. which made this knowledge lose all its salience for him. If he continued to possess knowledge of his court date, albeit latently, and it was only because of such an understandable disruption to his normal cognitive processes that he failed to appear in court, it is far less clear that the connection requirement would be satisfied. Thus, whatever role knowledge must play in actuating one's conduct in order for one to be properly punished as a knowing wrongdoer, we will need some principled way to decide when such latent or merely dispositional knowledge is or is not appropriately connected to one's conduct for it to be a proper basis for criminal sanctions

16. Throughout this article, "p" will be used as a variable designating a proposition and "A" will be used as a variable designating an action.

17. See Simons, supra note 9, at 236. See also infra, notes $46-49$ and accompanying text.

18. See infra notes $68-77$.

19. Jackson, 85 P.3d at 1043. 
These are the questions that this Article aims to illuminate, together with the analogous questions that arise about one's awareness of the risk when acting recklessly. In other words, this Article investigates the connection requirement as applied to the mens rea of knowledge and recklessness. While there has been substantial discussion of the connection requirement as applied to intent, ${ }^{20}$ the meaning of this requirement in the context of knowledge and recklessness crimes has received far less attention. In this Article, I consider one of the few sophisticated attempts to precisely spell out the requirement as applied to knowledge and recklessness-namely, the counterfactual approach offered by Ken Simons. ${ }^{21}$ However, I argue that this sort of approach faces serious problems. In its place, I defend a different kind of approach to the connection requirement-one that does not rely on counterfactual tests, but rather places normative questions front and center.

The order of business is as follows. Part I further elucidates the connection requirement and explains why it is substantially harder to give a satisfying account of this requirement for knowledge and recklessness than it is for intent. Along the way, it will become clear that knowledge and recklessness are structurally similar in ways that make them subject not only to similar questions, but also to similar answers. Part II explains an additional desideratum that accounts of the connection requirement for knowledge and recklessness should satisfy-namely, that it provide guidance in cases of latent or otherwise not-fully conscious knowledge or risk-awareness. With the challenges to be met thus more clearly in view, Part III proceeds to argue against Simons' counterfactual approach to the connection requirement for knowledge and recklessness. Finally, Part IV defends a distinct normative approach to the requirement that helps avoid the problems for Simons' account.

20. See, e.g., LAFAVE, supra note 8; DRESSLER, supra note 8, at 199-200; Simons, supra note 9, at 235-47; Geoffrey Marston, Contemporaneity of Act and Intention in Crimes, 86 L. Q. REV. 208 (1970); Alan White, The Identity and Time of the Actus Reus, 1977 CRIM. L. REV. 148 (1977); G. R. Sullivan, Cause and the Contemporaneity of Actus Reus and Mens Rea, 52 CAMBRIDGE L. J. 487 (1993); Peter W. Edge, Contemporaneity and Moral Congruence: Actus Reus and Mens Rea Reconsidered, 17 LIVERPOOL L. REV. 83 (1995); Stanley Yeo, Causation, Fault and the Concurrence Principle, 10 OTAGO L. REV. 213 (2002). Much of this literature concerns the relative timing of the mens rea and actus reus, which is a particularly vexing issue because the result required for the crime may not occur until well after the defendant's mens rea and conduct. However, many of these problems relate to causation. See Marston supra note 20 , at $218-19$.

21. See Simons, supra note 9. 


\section{THE CONNECTION REQUIREMENT GENERALLY AND THE SPECIAL DIFFICULTY CONCERNING KNOWLEDGE AND RECKLESSNESS}

\section{A. General Features of the Connection Requirement}

To start, consider an uncontroversial component of the connection requirement. It is generally agreed that the requisite connection between mens rea and actus reus involves some kind of temporal concurrence. ${ }^{22}$ At the very least, this means that one cannot be guilty of a crime if one only acquires the requisite mens rea after performing the required actus reus. ${ }^{23}$ For instance, "it is not robbery if the act of force or intimidation by which the taking is accomplished precedes the formation of the larcenous purpose."24 A similar point holds for knowledge crimes. ${ }^{25}$ As Simons notes, "if D now knows that the package he delivered for $\mathrm{E}$ contained illegal drugs, but came to this realization only after delivering the package, he is not guilty of knowingly transporting illegal drugs.,26 Thus, to be guilty of a crime requiring knowledge of a particular fact, the defendant at least had to possess the requisite knowledge during some part of $^{27}$ the performance of the actus reus of the crime (or perhaps the

22. LAFAVE, supra note 8 (noting that "it is sometimes assumed that there cannot be such concurrence unless the mental and physical aspects exist at precisely the same moment of time," though observing that this is not sufficient for the requirement to be satisfied). See also DRESSLER, supra note 8 at 199200.

23. See, e.g., Marston supra note 20, at 232-33 (noting that conviction is inappropriate "where the accused forms the mens rea after the completion of the actus reus of the crime"); Simons, supra note 9, at 250 ("[I]f the actor acquires a belief only after he completes the relevant act, the belief fails this 'connection' requirement and is irrelevant to criminal liability.").

24. LAFAVE, supra note 8; see also People v. Green, 609 P.2d 468, 501 (1980), abrogated on other grounds by People v. Martinez, 973 P.2d 512 (1999) ("We conclude that like the nonviolent taking in larceny, the act of force or intimidation by which the taking is accomplished in robbery must be motivated by the intent to steal in order to satisfy the requirement of [California Penal Code] section 20: if the larcenous purpose does not arise until after the force has been used against the victim, there is no 'joint operation of act and intent' necessary to constitute robbery." (emphasis added)).

25. For the criminal law definition of knowledge, see infra note 57.

26. Simons, supra note 9 , at 232.

27. Here is the reason for including the phrase "some part of" the actus reus. As Edge observes, "where the defendant has done all that he need to do during the currency of the mens rea, the coincidence requirement is satisfied even if the mens rea ceases to exist before the completion of the actus reus." Edge, supra note 20, at 85 . See also Marston, supra note 20, at 220 (discussing cases where 
lead-up to it or the preparation for $\mathrm{it}^{28}$ ). Likewise for recklessness crimes: ${ }^{29}$ to be guilty of such a crime, the defendant had to be aware of the relevant risk during some part of ${ }^{30}$ the actus reus (or perhaps its preparation $^{31}$ ).

There is a straightforward rationale for this rule that acquiring the mens rea after the actus reus has been completed will not support a conviction. If the defendant acquired the relevant mens rea, $\mathrm{M}$, only after doing the actus reus, then the defendant's possession of $M$ cannot have been any part of what produced or actuated the actus reus. ${ }^{32}$ As a result, the actus reus would not seem to manifest as much culpability as it would have were it performed with the required mental state, $M$.

Still, although possessing the requisite mens rea while commencing or carrying out the actus reus is generally necessary for conviction, ${ }^{33}$ it is

"the mens rea is formed after the commencement but before the end of the" actus reus).

28. Jackson might seem to suggest that one's knowledge can be adequately connected to the actus reus even if it was consciously entertained only in the lead-up to or while preparing for the actus reus. The court noted in dicta that "Jackson would be guilty of 'knowingly' failing to appear if he decided early on that he would not attend his scheduled court appearances, and he then dismissed the matter from his mind." Jackson v. State, 85 P.3d 1042, 1043 (Alaska Ct. App. 2004). Nonetheless, it is not obvious that this would be a case in which the defendant possesses the relevant knowledge before doing the actus reus, but not during it. After all, even if Jackson had "dismissed the matter from his mind" on the date he was scheduled to be in court, he still plausibly would have possessed the knowledge of his court date at least latently. Even if he did not consciously attend to this knowledge while failing to appear, he nonetheless still would possess the knowledge.

Accordingly, I take no official stand on whether it is possible for knowledge to be adequately connected to the actus reus if this knowledge is possessed only before, but not during, the performance of the actus reus. I don't wish to foreclose the possibility that knowledge might be part of what actuates the defendant's performance of the actus reus, even if the defendant no longer possesses this knowledge when he actually goes on to perform it. But I also cannot confidently assert that this does occur. More conceptual work is needed to settle the matter conclusively.

29. For the criminal law definition of recklessness, see infra note 59.

30. Cf. supra note 27.

31. Cf. supra note 28.

32. See LAFAVE, supra note 8 (noting that in cases where "the bad state of mind follows the physical conduct...it is obvious that the subsequent mental state is in no sense legally related to the prior acts or omissions of the defendant"). $C f$. People v. Green, 609 P.2d 468, 501 (1980).

33. One possible exception is a

case in which $A$ decides to kill $B$, and then voluntarily becomes intoxicated for the purpose of nerving himself for the accomplishment of his plan, and then, 
clearly not sufficient to satisfy the connection requirement. ${ }^{34}$ Crimes $^{3}$ requiring the mens rea of intent most easily illustrate the point. Consider an example from Simons (slightly simplified). ${ }^{35}$ Suppose Bill is driving to his uncle's house intending to shoot and kill him. While driving, Bill is consumed with thoughts of how nice it will be to have his uncle dead, which results in Bill not paying adequate attention to the road. As a result of his careless driving, he negligently hits and kills a pedestrian who happens to be his uncle. ${ }^{36}$ In this case, Bill would not be guilty of murder, even though he possesses the requisite mens rea-i.e. the intent to kill his uncle-at the same time as his conduct that causes the death of his intended victim. The explanation for this is that the connection requirement is not satisfied. The conduct of Bill's that results in his uncle's death, while temporally concurrent with Bill's intention to kill

while intoxicated, kills $B$. Assuming that $A$ had the required mental state prior to intoxication, but then became so intoxicated as to be unable to have such a mental state, is he guilty of murder? Most courts have said yes.

LAFAVE, supra note 8 (internal citations omitted). One possible reading of this case is that the connection requirement was not satisfied when A performed the act that resulted in B's death. Nonetheless, it's also plausible that the connection requirement would be satisfied if getting drunk was the intended means by which A sought to secure B's death. If so, then A would at least have the required intent to kill during some part of the conduct intended to culminate in B's death-i.e. when he commences that course of conduct. Accordingly, one might also argue that the connection requirement is indeed satisfied in this case.

The trickier case is the one in which A got blackout drunk by accidentally drinking too much, and then killed B in some unforeseen way. Then it is far from clear that the connection requirement is satisfied. Perhaps courts would convict on the theory that voluntary intoxication is no defense under such circumstances. However, one might fairly question whether this would be a theoretically sound result.

34. See LAFAVE, supra note 8 (noting that "[a]lthough it is sometimes assumed that there cannot be such concurrence unless the mental and physical aspects exist at precisely the same moment of time, ... mere coincidence in point of time is not necessarily sufficient"); see also DRESSLER, supra note 8, at 199-201 (noting that in addition to temporal concurrence, what he calls "motivational concurrence" is also required).

35. Simons, supra note 9, at 232. See also Marston, supra note 20, at 232 (discussing the same hypothetical).

36. Simons' original example (which he, in turn, culls from Searle) might be explained away by appeal to the voluntary act requirement. In the initial example, the car accident happens because Bill is "so nervous and excited that he accidentally runs over" his uncle. Simons, supra note 9, at 232. But this might make it sound as though the accident was caused by Bill's hands shaking or the like, in which case it would be questionable whether the death was caused by voluntary conduct. I endeavored to tell the story in a way that avoids this worry. 
his uncle, is not the execution of that intention. That is, his negligent driving is not undertaken in order to, or as a means to, accomplishing his goal or purpose of killing his uncle (which, in turn, he might desire as an end in itself or as a means to something else he wants, say, inheritance money).

It is in part because of cases like this that Wayne LaFave concludes that the required connection between actus reus and mens rea is not primarily a matter of temporal concurrence; rather, "the better view," he argues, is that the requirement is satisfied "when the defendant's mental state actuates the physical conduct." ${ }^{, 37}$ In this, I think he is correct. ${ }^{38}$ In a similar vein, Dressler observes that " $[\mathrm{t}]$ he defendant's conduct that caused the social harm must have been set into motion or impelled by the thought process that constituted the mens rea of the offense." 39 Simons' view, too, is similar to LaFave's and Dressler's, but he helpfully puts some additional meat on the bones of this idea. He observes that the defendant's intent to kill must connect to his conduct-i.e. actuate it-in the following way in order for the connection requirement to be satisfied:

(a) When he acted, D believed that his actions could bring about V's death,

(b) V's death is what D desired or planned, and

(c) D took those actions in order to bring about, or as part of a plan to bring about, V's death. ${ }^{40}$

In Bill's case, prong (c) is not satisfied. His careless driving was not undertaken in order to, or as an execution of his intent to, kill his uncle.

The failure of the connection requirement to be satisfied in this case also has implications for the culpability of Bill's conduct. The claim that the connection requirement is not satisfied in Bill's case is just another way to say that Bill's intention to kill his uncle was not expressed in the conduct that in fact caused his uncle's death. And because this intention was not expressed in his conduct, the conduct did not manifest the amount of culpability normally associated with an intentional killing. The basis for this conclusion is a particular theory of culpability, which

37. LAFAVE, supra note 8.

38. The Jackson court agreed. See Jackson v. State, 85 P.3d 1042, 1043, n.4 (Alaska Ct. App. 2004) (citing 1 WAYNe LaFave, Substantive Criminal LAW $\S 6.3$ (a) and formulating the connection requirement in terms of actuation).

39. DRESSLER, supra note 8 , at 199 (emphasis added).

40. Simons, supra note 9, at 236. 
Simons is sympathetic to ${ }^{41}$ and which I assume for purposes of this paper:

Insufficient Regard Theory: The degree to which a particular action is culpable equals the degree to which that action manifests insufficient regard for others or their legitimately protected interests (or ill will, for short). ${ }^{42}$

How does this theory relate to the connection requirement? If a particular mental state, $\mathrm{M}$, of the actor's is not appropriately connected to his action, $\mathrm{A}$, then $\mathrm{A}$ will not manifest the amount of insufficient regard that $\mathrm{A}$ would have manifested were it appropriately connected to $\mathrm{M}$. Because Bill's conduct was not appropriately connected to his intention to kill his uncle, this conduct did not manifest the amount of insufficient regard, and thus culpability, that it would have done had he behaved the same way and the connection requirement were satisfied. Instead, his actual conduct was at most negligent with respect to his uncle's death, and so this conduct would at worst manifest the amount of insufficient regard associated with negligent homicide. (More must obviously be said about what it is for an action to manifest a particular amount of insufficient regard, and I will clarify the matter further in Part III.)

For purposes of this Article, I have no quarrel with Simons', LaFave's, or Dressler's claims about the connection requirement when it

41. This is evident, for example, in Simons' discussion of the culpability of "[t]he torturer who leaves the victim to die, and the Russian roulette player who willingly imposes a one in six chance of death for a personal thrill, each [of whom] displays grossly insufficient concern for the interests of their victims." Simons, supra note 9, at 261 (emphasis added). Simons' sympathy for the present view of culpability is also apparent in his explanation of the culpability of knowing or reckless misconduct in general:

If a person acts despite his belief that he is likely to cause harm, or despite his belief that he has created a significant risk of harm (or if he acts despite his belief that an inculpatory circumstance is likely or is a substantial risk), then his culpability arises from his failure to give sufficient weight to that consideration in his conduct.

Id. at 249-50 (emphasis added).

42. See also Nomy ARPAly \& Tim Schroeder, In PRAISE of Desire 170 (2013) ("[A] person is blameworthy for a wrong action A to the extent that A manifests ill will (or moral indifference) through being rationalized by it"). This theory is also roughly equivalent to the theory that an action is culpable to the degree that it displays the actor's faulty modes of recognition and response to reasons. GIDEON YAFFE, ATTEMPTS 38 (2011) (discussing the theory that conduct deserves censure (or blame) if and only if "it is a product of a faulty mode of recognition or response to reasons for action"). 
comes to intent. ${ }^{43}$ Instead, what the remainder of the Article investigates is the connection requirement as applied to knowledge and recklessness. The reason for this focus is that getting a fix on the connection requirement for these two mental states turns out to be significantly more difficult than it is for intent. ${ }^{44}$

\section{B. Why the Requirement Is Trickier for Knowledge and Recklessness: Desideratum 1}

Whence the extra difficulty concerning knowledge and recklessness? To start, note that it's fairly clear what it means for the mental state of intent to actuate some bit of physical conduct, to use LaFave's term. ${ }^{45}$ Roughly, the conduct must be the execution of an intention one has, i.e. something done as a means to an end one possesses. However, it is far less obvious what it is for knowledge or recklessness to actuate, produce or issue in some bit of conduct. ${ }^{46}$ Granted, a knowing or reckless wrongdoer is often said to act "despite"

43. Others have extensively discussed additional complications concerning the connection requirement as applied to intent. See supra note 20 and accompanying text.

44. Formulating the connection requirement for negligence is likely to be yet more difficult, and so I set aside that task for later. George Sher's excellent book on related questions offers an account of responsibility for negligent action that goes a long way towards specifying the conditions that must be met for a particular action to be appropriately connected to one's negligent mental state in order for that action to manifest insufficient concern for the interests of others (although he does not discuss the problem precisely in terms of the connection requirement). See GEORGE SHER, WHO KNEW? RESPONSIBILITY WITHOUT AWARENESS 85-95, 141-54 (2009); see also Simons, supra note 9, at 257-59.

45. LAFAVE, supra note 8 .

46. A similar point applies to Dressler's claim that " $[\mathrm{t}] \mathrm{he}$ defendant's conduct that caused the social harm must have been set into motion or impelled by the thought process that constituted the mens rea of the offense." DRESSLER, supra note 8, at 199 (emphasis added). What does it mean for a mental state like knowledge or recklessness to "set into motion" or "impel" the conduct of the defendant? It would be clear what this means if the knowledge or recklessness in question involved an instrumental belief of the form if I perform the actus reus, I know (or believe there is a substantial chance) that I will accomplish my goal $G$. But in the vast majority of cases, the knowledge required for conviction of a knowledge crime, or the risk one must be aware of to be guilty of a recklessness crime, does not involve an instrumental belief of this kind. Thus, the question remains as to how a mental state like knowledge or recklessness can be part of the motivational force behind the defendant's performance of the actus reus. I answer this question in Part IV of this paper. 
his knowledge or his awareness of a risk. ${ }^{47}$ But this merely restates in different terms the puzzling idea to be explained.

The challenge in explaining what is involved in knowledge or recklessness producing some bit of conduct is compounded by the fact that the traditional tools of action theory initially seem to come up short. In the core case where a defendant commits a crime that requires knowledge of some fact, or awareness of some risk, the defendant's conduct clearly will be performed for some reason or other. If I knowingly receive stolen property, for example, this will involve my performing some bit of voluntary conduct-say, picking up the goods I know to be stolen and putting them in the trunk of my car-and it will be the case that I do this for some reason-say, to get the financial benefits of possessing these goods. Let " $R$ " designate the reason for which I act here. Following a venerable tradition in action theory, we may take this reason, $\mathrm{R}$, to consist of the considerations that, together with one's desires and other instrumental beliefs, rationalize this action and nondeviantly cause it in virtue of rationalizing it. ${ }^{48}$ What appears odd, though, is that my culpable knowledge in this case-i.e. that the goods are stolen-does not figure into the reason for which I performed the conduct in question (i.e. for which I put the goods in my car). How, then, can this piece of knowledge be active in producing my conduct? Only if this knowledge is part of what produces or actuates my conduct would it seem to be connected to that conduct in a way that allows this knowledge to help determine the amount of culpability my conduct manifests.

As a result, one central question that our account of the connection requirement should answer is how one's knowledge of a fact, or awareness of a risk, can be causally active in producing a particular action (i.e. actuate it), and the account should explain how this is possible even though the knowledge or risk-awareness does not directly figure into the reason for which that action was done. Providing such an

47. See, e.g., Alan C. Michaels, Acceptance: The Missing Mental State, 71 S. CAL. L. REV. 953, 967 (1998) ("What makes the knowing actor morally culpable is her action connected with her knowledge. It is the action in spite of the knowledge."); Kenneth W. Simons, Statistical Knowledge Deconstructed, 92 BOSTON UNIV. L. REV. 1, 16 (2012) (noting that "we hold [a knowing or reckless actor] responsible for her willingness to act notwithstanding her belief that her actions will or might cause harm").

48. See ARPALY \& SCHROEDER, supra note 42. On their view, "[t]o think or act for a reason is for the event of one's thinking or acting to be caused (or appropriately causally explained) by one's other attitudes in virtue of the fact that these attitudes [i.e. their contents] rationalize (to some extent) the thought or action." (emphasis omitted) $I d$. at 62 . 
explanation, I'll say, is Desideratum 1 for an account of the connection requirement for knowledge and recklessness. ${ }^{49}$ The account of the connection requirement I will offer in Part IV of this article aims to provide the sort of explanation that is needed to satisfy Desideratum 1 .

Two clarifications before proceeding. First, I assume the answer to the question behind Desideratum 1 should ideally fall within the causalist tradition in action theory-i.e. it should illuminate how knowledge or risk-awareness can be among the causes of an action. ${ }^{50}$ The reason for this is not just that the causalist tradition is arguably the dominant approach in contemporary action theory; ${ }^{51}$ in addition, this approach is suggested by LaFave's talk of the need for the mens rea to "actuate" the actus reus. ${ }^{52}$ The second clarification is that, while satisfying Desideratum 1 requires saying what sort of causal connection satisfies the connection requirement, it will not do to just stipulate that so-called "deviant causation" 33 prevents the requirement from being satisfied. It appears there can be cases of deviant causation involving knowledge where the connection requirement intuitively is satisfied. ${ }^{54}$

49. We need not posit a similar desideratum for accounts of the connection requirement for intent because it is relatively clear what's involved in an intention actively producing an action: the action must be the execution of some relevant intention. Cf. Simons, supra note 9, at 236.

50. This tradition, which traces back to Davidson's seminal work on intentional action, takes it (roughly) that explanations of a person's actions in terms of her reasons for so-acting are a species of causal explanation. See generally DONALD DAVIDSON, ESSAYS ON ACTIONS AND EVENTS (1980); JESUS H. AgUILAR \& ANDrei A. BuckarefF, eds., Causing Human actions: New Perspectives ON THE CAUSAL THEORY OF ACTION (2010).

51. "[T] $]$ he view that reason explanations are somehow causal explanations remains the dominant position." G. Wilson and S. Shpall, Action, STANFORD ENCYCLOPEDIA OF PHILOSOPHY, Edward N. Zalta (ed.) (2012), http://plato.stanford.edu/archives/sum2012 /entries/action/.

52. See LAFAVE, supra note 8. Not only is some kind of causalist explanation suggested by LaFave's talk of "actuation," but the same is also supported by Dressler's talk of the defendant's conduct being "set into motion or impelled by the thought process that constituted the mens rea of the offense." DRESSLER, supra note 8, at 199.

53. See, e.g., Rowland Stout, Deviant Causal Chains, in A Companion to THE PHILOSOPHY OF ACTION 159 (Timothy O'Connor \& Constantine Sandis eds., 2010); DAVIDSON, supra note 50, at 79.

54. Here is one such case. (I am grateful to Erik Encarnacion for suggesting it.) Suppose Fred gets a thrill from starting fires that he believes to be highly likely to lead to another person's death. Thus, he will only start the fire if he believes it highly likely that someone will be inside the building he intends to burn down and will die in the fire. He will not start a fire if he's pretty sure that someone won't be in the building. Moreover, he does not directly desire or intend 


\section{FURTHER DIFFICULTIES WITH THE CONNECTION REQUIREMENT FOR KNOWLEDGE AND RECKLESSNESS: LATENT KNOWLEDGE OR RISK-AWARENESS}

In addition to Desideratum 1 , this Part introduces a second desideratum that our account of the connection requirement should satisfy. In particular, as I will explain, the account should accommodate cases of latent or otherwise not-fully-conscious knowledge or riskawareness. As Simons notes:

[T]he requirement does become problematic in those frequent situations when the actor has only latent awareness of a relevant risk or fact, or when the actor acquires his belief well in advance of the criminal act, and then, because of forgetfulness, distraction, or preoccupation, fails to access that prior belief when he acts. ${ }^{55}$

Desideratum 2, then, is that our account enables us to plausibly distinguish cases involving not-fully-conscious knowledge or riskawareness where the connection requirement is satisfied from cases of this type where the requirement is not satisfied.

To show the force of this challenge, it will be helpful to explain in detail why mere temporal concurrence is not sufficient to satisfy the

anyone's death. He desires and intends only to risk the death of another. The explanation for all this is that, under Fred's peculiar psychology, he cannot get the thrill he seeks unless he satisfies the law's knowledge requirement, but he'll get the thrill only if he's in that epistemic state.

One day Fred approaches the building he plans to set alight, his knowledge of the person in the building makes him very excited. As a result, while in the process of sabotaging the wiring in the building to start the fire, his excitement owing to the belief that someone in building causes him to get distracted and he is careless in his sabotage effort. Thus, the wiring happens to catch fire in an unexpected way. The fire starts prematurely and only burns down the west wing of the building, where Fred believed someone to be present. The fire kills the person in the west wing.

Fred is guilty of murder. After all, he has knowledge that his conduct will cause a death and it did. Nonetheless, there is only a very attenuated causal connection between his knowledge and the death. This is a classic case of socalled "deviant causation," that is, a case where one accomplishes what one set out to do but only in an accidental or freakish way.

Despite this deviant causal connection between Fred's knowledge and his conduct, there is a strong basis for taking Fred to be guilty of murder-a crime for which knowledge suffices. Thus, we need an explanation of why such a case of deviant causation apparently suffices for being guilty of a knowledge crime. My account in Part IV will explain why the connection requirement is indeed satisfied in the case of Fred.

55. Simons, supra note 9 , at 248. 
connection requirement for knowledge or recklessness. The central reason why temporal concurrence does not suffice (as we will see) is that it is possible for a person, while acting, to possess the required piece of knowledge, or awareness of the relevant risk, even though that knowledge or risk-awareness is not a relevant part of what produced (or actuated) the defendant's conduct. I will say that such mental states are not expressed in action. One aim of this Part, therefore, is to show that there are cases in which the actor genuinely possesses the mental state of knowledge or recklessness while acting, but that mental state remains unexpressed-i.e. the connection requirement is not satisfied. Let me first clarify what the mental states of knowledge and recklessness are before explaining how they might fail, even when present, to be expressed in action.

\section{A. Clarifying Knowledge and Recklessness}

The mental states of knowledge and recklessness can both be modeled as cognitive states (or simply beliefs) concerning the probability that a particular inculpatory proposition is true. ${ }^{56}$ In other words, they can be understood in terms of one's degree of subjective certainty or confidence in the truth of the inculpatory proposition. The inculpatory proposition will generally be the claim that some element of the crime obtains-whether this is that some result will ensue (e.g. death), that some attendant circumstance is present (e.g. that the building one enters is a dwelling), or that one's conduct is of a particular nature (e.g. illegal). Accordingly, knowledge in the criminal law consists in possessing a degree of confidence in the inculpatory proposition that is high enough to count as "practical certainty," or seeing its truth as "highly probable," provided the inculpatory proposition also is in fact true. ${ }^{57}$ (Note that this is notion of knowledge is significantly weaker than the one used by

56. See Alexander Sarch, Willful Ignorance, Culpability and the Criminal Law, 88 ST. JOHN's L. REV. 1023, 1031-1034 (2014).

57. On the Model Penal Code (MPC) definition, "[a] person acts knowingly with respect to a material element of an offense" when he is "aware" or "practically certain" that the element obtains (depending on what sort of element it is). MPC $\S 2.02(2)$ (b) (Official Draft and Revised Comments 1985). The MPC further clarifies that "[w] hen knowledge of the existence of a particular fact is an element of an offense, such knowledge is established if a person is aware of a high probability of its existence, unless he actually believes that it does not exist." MPC § 2.02(7) (emphasis added). More simply, as Robin Charlow explains, in the criminal law "knowledge requires both belief, or subjective certainty, and the actual truth or existence of the thing known." Robin Charlow, Wilful Ignorance and Criminal Culpability, 70 TEX. L. REV. 1351, 1375 (1992). 
philosophers. ${ }^{58}$ ) Recklessness, then, differs from knowledge mainly in that it does not require having as high a degree of confidence that the relevant material element obtains--i.e. one does not have to see the truth of the inculpatory proposition as "highly probable" or a "practical certainty." Instead, for recklessness, it suffices that one acts despite being aware of a "substantial" probability that the relevant material element obtains, provided the risk of its obtaining is unjustified. ${ }^{59}$

As several legal scholars have noted, one's estimate of the probability that a material element obtains (i.e. one's subjective confidence in the inculpatory proposition) does not have to be consciously attended to when acting. ${ }^{60}$ For example, I can be aware that my speeding down a crowded city street poses a substantial and unjustified risk of death even if I am not currently thinking to myself, or consciously attending to the fact, that my driving is likely to kill someone. Instead, I might simply be peripherally or pre-consciously aware of the risk of death I am imposing, feel it in my gut, or otherwise possess the relevant subjective confidence of the risk without this being the content of an occurrent thought at the time. Perhaps my only occurrent thought is that the street is crowded.

\section{B. How Knowledge and Recklessness Can Be Actually Present During the Actus Reus but Remain Unexpressed}

Now we are in a better position to see how such mental states, which the defendant possesses at the time of her action, nonetheless

58. In the epistemology literature, knowledge is typically taken to require i) justified ii) true iii) belief, plus iv) some additional condition designed to get around so-called "Gettier counterexamples." $C f$. Jonathan J. Ichikawa and Matthias Steup, The Analysis of Knowledge, THE STANFORD ENCYCLOPEDIA OF PHILOSOPHY (2012), http://plato.stanford.edu/entries/knowledge-analysis/ ("Most epistemologists have accepted Gettier's argument, taking it to show that the three conditions of the JTB account-truth, belief, and justification-are not in general sufficient for knowledge.").

59. "A person acts recklessly with respect to a material element of an offense when he consciously disregards a substantial and unjustifiable risk that the material element exists or will result from his conduct." MPC $\S 2.02(2)(c)$.

60. See Douglas N. Husak, Distraction and Negligence, in,PRINCIPLES AND VALUES IN CRIMINAL LAW AND CRIMINAL JUSTICE: ESSAYS IN HONOUR OF ANDREW ASHWORTH 81, 85 (Lucia Zedner \& Julian V. Roberts eds., 2d ed. 2012) ("It is clear that defendants need not have an explicit thought about the risk before their conscious minds in order to be reckless. In other words, reckless persons need not be saying to themselves 'this is risky' when they inflict injury. (...) $[\mathrm{F}]$ ew of us would ever be reckless if we needed to rehearse such thoughts at the moment we cause harm."). 
might fail to be expressed in that action. This, in turn, shows why possessing the mens rea of knowledge or recklessness while performing the actus reus is not sufficient to satisfy the connection requirement. In order to establish this point, I will sketch a hypothetical case involving latent knowledge. ${ }^{61}$ (A similar point could also be made about latent risk-awareness. But given the similarities between knowledge and recklessness, it is easy to see how that would go. So the discussion focuses just on knowledge.)

Note that I could also have made the present point using a variation on the facts of Jackson, in which the defendant fails to appear in court only because he receives some shock to his system that renders his knowledge merely latent or insalient. ${ }^{62}$ However, Jackson involves an omission-i.e. the failure to appear-which might seem to be a complicating factor. ${ }^{63}$ Accordingly, the hypothetical I rely on involves overt action, not omission.

Consider, then, Frank the fund manager. Frank's business involves collecting investments from private investors and passing them through to larger investment managers. One morning, an analyst in his employ shows him strong evidence that Bernie, one of the investment managers with whom Frank is considering investing his clients' funds, is perpetrating a massive fraud. Frank resolves not to have any further dealings with Bernie. However, that afternoon, as Frank is about to approve or reject the transfers from his clients' funds to different investment managers (including Bernie), Frank receives word that his family has been in a terrible car accident. He is stunned. As he is about to rush to the hospital, his callous supervisor tells him that he must sign the documents concerning the transfers of funds before he can leave. Frank, distressed to distraction, quickly signs the documents approving all of the transfers, including one to Bernie. While signing, Frank has the sneaking suspicion that there was an issue with one of the transfers, and that it might be a bad idea to approve them all, but in his distracted state he simply rushes ahead. Frank had not forgotten or otherwise lost access to his knowledge of Bernie's fraud, but the shocking news sent him reeling in such a way that the knowledge was no longer salient for him. Still, had Frank stopped to consider for one moment, he would have

61. See infra notes $68-77$.

62. See supra notes $18-19$ and accompanying text.

63. The metaphysics and ethics of omissions are notoriously tricky. See, e.g., Jonathan Schaffer, Causes Need Not be Physically Connected to Their Effects: The Case for Negative Causation, 197-216, Christopher Hitchcock (ed.), CONTEMPORARY Debates IN PHILOSOPHy OF ScIENCE (2004), http://www.jonathanschaffer.org/negcause.pdf. 
recalled Bernie's fraud and would not have approved the transfer of funds to him. ${ }^{64}$

Is Frank guilty of aiding and abetting Bernie's fraud? This crime requires not only an intentional act in aid of the principal wrongdoer's conduct (i.e. Frank's approval of the transfer to Bernie), but also the knowledge that the underlying crime is being committed. ${ }^{65}$ Here, Frank in some sense knows that Bernie is engaged in a fraud. If prompted, Frank would instantly agree that he is practically certain that Bernie's investment activities are fraudulent. Frank has not completely forgotten the analyst's warning from that morning or otherwise lost access to the information. Rather, because of his distress, he simply failed to attend to this knowledge at the time. It lost the salience for him that it would have had under normal conditions. Accordingly, Frank's distress blocked the knowledge from playing the role in his deliberations and actions that it would have played under normal circumstances. Thus, even though Frank knew at the time he acted in aid of Bernie's crime that Bernie was perpetrating a fraud, this knowledge does not seem appropriately connected to Frank's action. That is, the knowledge is not connected to his action in a way that demonstrates that he gave too little weight to the existence of the fraud or otherwise reveals that he was insufficiently concerned with the interests of the victims of the fraud. As Simons explains, in cases like this:

the actor who at some point in the past possessed a legally relevant belief and now encounters the risk does not necessarily reveal the presumptive culpability characteristic of knowing actors-namely, that their actions show that they give far too little weight to a highly probable harm in their practical reasoning and action. Rather, in such cases, the actor fails (for some reason) to give the risk any weight at all. $^{66}$

64. An even more extreme version of this example might be one in which Frank was himself subject to some traumatic experience-perhaps he was in a car accident himself on the way back from a meeting, but before being allowed to go to the hospital, he was forced to sign the documents. Still, receiving news that one's family was in an accident should itself be an example of a sufficiently egregious shock to make the point in question here.

65. Under federal law, whoever "aids, abets, counsels, commands, induces or procures" a crime "is punishable as a principal." 18 U.S.C. $\S 2(a)$. The U.S. Supreme Court recently noted that it had "previously found [the] intent requirement [for aiding and abetting] satisfied when a person actively participates in a criminal venture with full knowledge of the circumstances constituting the charged offense." Rosemond v. United States, 134 S. Ct. 1240, $1248-49$ (2014).

66. See Simons, supra note 9 , at 252. 
Accordingly, since the connection requirement does not seem to be satisfied as between Frank's knowledge and his action in aid of Bernie's crime, we have reason to conclude that Frank should not be guilty as an aider and abettor.

\section{A Worry: When Is Latent Knowledge Really Knowledge?}

Now, the obvious objection to this line of reasoning is to say that if Frank is not guilty of aiding and abetting Bernie's crime, this is only because Frank does not actually possess knowledge of Bernie's crime at the time Frank does his act in aid of it. It is not, as I claimed, because Frank's knowledge, though possessed concurrently with his action, is not appropriately connected to that action. ${ }^{67}$

Nonetheless, this objection is unconvincing. Even if it might be prudent for defense counsel to claim that Frank did not possess actual knowledge of the fraud at the time he signed the transfers (after all, the connection requirement is a relatively unfamiliar doctrine), the fact remains that any plausible account of knowledge possession would have to count Frank as actually knowing of Bernie's fraud while signing the transfers. The argument I will offer for this claim is that Frank's knowledge of the fraud is a form of latent knowledge, which uncontroversially can constitute actual knowledge and be manifested in action. If latent knowledge can indeed constitute actual knowledge, then Frank's knowledge of the fraud likewise counts as actual knowledge. Accordingly, the best way to understand the case is to say that Frank's actual knowledge of the fraud is blocked, screened off, or rendered non-

67. Another possible objection is that perhaps Frank is not guilty of aiding and abetting only because he is excused, not because (as I claimed) the connection requirement fails to be satisfied. (Thanks to Steven Schaus for this objection.) However, one might describe the fact that the connection requirement is not satisfied to be one type of excusing or otherwise exculpating factor. (After all, it is not merely a mitigator that supports giving a lesser sentence.) One might object that it is usually the defendant's burden to prove an excuse, not the prosecution's burden to prove the absence of an excuse. And when it comes to the connection requirement, it is the prosecution's burden to prove that it is satisfied-thus making the connection requirement like an element of the crime. That would be a problem for my claim that the connection requirement being unsatisfied looks like an excuse. Nonetheless, it is in fact not a problem because, plausibly, in most cases we just presume that the connection requirement is satisfied, and it is only if the defendant raises the claim that it's not satisfied that the issue is ever litigated. (Granted, that does not mean that it is formally the defendant's burden to prove that the connection requirement is unsatisfied, but in practice matters seem to work in a way that is quite close to this.) 
salient by his distraction, such that this knowledge is not appropriately connected to, or expressed in, his act in aid of Bernie's fraud. Or so I will argue.

To make good on this argument, begin by noting that the morning Frank was told of Bernie's fraud, he clearly had knowledge. Moreover, in the afternoon (when Frank received the shocking news about his family), Frank had not lost the ability to access this information. Even after being told of his family's accident, Frank still could easily have brought the information to consciousness if prompted or if simply given the opportunity to calmly reflect for a moment. He remains able to use this knowledge in deciding how to act (at least under normal circumstances). Accordingly, Frank's access to this information is just like our access to a great deal of the beliefs we possess, but to which we do not consciously attend or which do not figure into the content of an occurent thought.

Such knowledge is often dubbed latent knowledge, ${ }^{68}$ and it is a pervasive phenomenon. To borrow some examples from Simons, if I loaded my gun this morning, it is plausible that $\mathrm{I}$ :

'know' that the gun is loaded, not in the sense of vivid current conscious awareness of this fact, but in the straightforward sense that I would readily concede the fact if I were asked and were to reply honestly. In the latter sense, I 'know' that $2+2=4$, and that [Barack Obama] is our current President, even when those beliefs are not conscious, and are not occupying my thoughts. ${ }^{69}$

Likewise, Doug Husak mentions a "marksman who fires his weapon at a distant target," and although he "does not think to himself "I might miss"," he nonetheless knows he might. ${ }^{70}$

I submit that in these examples, the respective individuals know the relevant propositions-even though they are not consciously attending to these propositions at the time. Here is why. Criminal law takes knowledge to be, essentially, true belief. ${ }^{71}$ The truth of the propositions

68. See, e.g., Alan James MacFadyen, Beliefs in Behavioral and Neoclassical Economics, in HANDBOOK OF CONTEMPORARY BEHAVIORAL ECONOMICS: FOUNDATIONS AND DEVELOPMENTS (Morris Altman ed. 2006) 183, 185-86 (discussing ways in which the term "belief" might be "applied to something that lies hidden in the unconscious" and using the term "latent belief" to denote "unconscious beliefs that would be recognized as beliefs if brought to our attention").

69. Simons, supra note 9 , at 251.

70. Husak, supra note 60 , at 85 .

71. As Robin Charlow explains, in the criminal law "knowledge requires both belief, or subjective certainty, and the actual truth or existence of the thing 
in the examples quoted above is assumed, so the subjects know the relevant propositions if and only if they believe them. While it is notoriously difficult to specify the precise conditions in which a person, $\mathrm{S}$, counts as believing that $\mathrm{p}$, any adequate theory of belief would regard the people in these examples as believing the relevant propositions. ${ }^{72}$ As Husak explains, the standard analysis of belief is dispositional. ${ }^{73}$ That is, a person believes that $p$ "when he has the disposition to behave in given ways" that are characteristic of believing that $p$, "most notably when he has the disposition to assent to utterances of $p$ in the right sorts of circumstance ([e.g.] when he comprehends the language, has no stake in deception, and the like)."74 Others have defended more sophisticated dispositional accounts, ${ }^{75}$ while still others prefer non-dispositional

known." Charlow, supra note 57, at 1374-75 (1992) (observing that "criminal knowledge is correct belief").

72. See Husak, supra note 60 , at 85 (noting that contemporary epistemologists "have said disappointingly little about" the conditions under which $\mathrm{S}$ believes $\mathrm{p}$, but observing that "an adequate analysis ... would support the conclusion that our marksman is well aware of the risk of missing his target-even though his belief is not occurrent").

73. See id. at 85.

74. Id. at 85-87. See generally Douglas N. Husak, Negligence, Belief, Blame and Criminal Liability: The Special Case of Forgetting, 5 CRIM. L. \& PHIL. 199, 210-14 (2011). Note that Husak's question in these two papers is different from the question I am concerned with here. Husak aims to answer the question of when latent belief-whether it involves distraction or forgetting or something else-suffices for actual knowledge (in the case of a latent practical certainty) or recklessness (in the case of a latent awareness of a substantial risk), as opposed to plain negligence. By contrast, my question concerns cases in which we are already confident that latent belief does amount to actual knowledge or recklessness: in such cases, when should we regard the connection requirement as satisfied and when should we regard it as unsatisfied? An overriding aim of the present Part, then, is to argue that there can be instances in which latent belief does amount to actual knowledge, but the connection requirement still is not satisfied. (The case of Frank is one such instance.)

75. See Eric Schwitzgebel, In-Between Believing, 51 PHIL. Q. 76, 76-81 (2001) (arguing that to determine if an unclear case genuinely counts as belief, one should look to the extent to which the individual possesses a sufficient degree of the stereotypical dispositions that are characteristic of belief; "the greater the proportion of stereotypical dispositions a person possesses, and the more central these are to the stereotype, the more appropriate it is to describe him as having the belief in question."). See also Eric Schwitzgebel, Acting Contrary to Our Professed Beliefs, or the Gulf Between Occurrent Judgment and Dispositional Belief, 91 PAC. PHIL. Q. 531, 533-36 (2010) [hereinafter Schwitzgebel (2010)] (discussing cases of "in-between" belief); Ruth Marcus, Some Revisionary Proposals about Belief and Believing, 50 PhIL. \& Phenomenological Res. 
approaches. $^{76}$ I take no stand on what the correct analysis of belief is. I note only that on whatever account proves correct, the individuals in the examples quoted above will count as believing the relevant propositions. After all, they possess the required dispositions-e.g. they would assent to the relevant propositions in the right circumstances, they would tend to behave as if the propositions were true, etc. Accordingly, because the individuals in the quoted examples believe the relevant propositions, and they are actually true, they have knowledge of these propositions in the criminal law sense.

In general, then, I will use the term "latent knowledge" to denote the mental state $S$ bears towards $p$ when: (1) despite not occurrently believing that $\mathrm{p}$, (2) $\mathrm{S}$ nonetheless possesses enough subjective confidence in $\mathrm{p}$ to qualify as believing that $\mathrm{p}$ according to whatever dispositional account of belief proves correct, and (3) p really is true. ${ }^{77}$ "Latent risk-awareness" can be understood analogously.

Not only is it possible to have actual knowledge of a proposition despite believing it only latently, but such latent knowledge clearly can also be active in producing action. To take a simple example, suppose I sleep through my alarm and see when I wake that the time is 8:30 a.m. I know I have to be at work by 9 a.m. or face a penalty, which I want to avoid. Still, suppose all I can think about that morning are various excuses I might tell my boss. Nonetheless, the belief that (together with the relevant desires) motivates me to hurry out the door is the belief that I will be penalized for being late unless I rush to work. The belief that I will be penalized for being late is thus latent in the relevant sense, although it clearly plays a central role in producing and explaining my actions. Less banal examples are also easy to come by. Consider my belief that speeding down a crowded city street is virtually certain to

133, 133-53 (1990) (arguing that believing that $p$ is to act in relevant circumstances as if p were true); David Hunter, Alienated Belief, 65 DIALECTICA 221,238 (2011) (arguing that to believe that $p$ "is to be disposed to act and react in ways that would advance one's plans and achieve one's goals if $\mathrm{P}$ were the case").

76. See Schwitzgebel (2010), supra note 75, at 535-36 (discussing functionalist, representationalist and interpretationist accounts of belief possession).

77. Latent knowledge thus is similar in some ways to what Ferzan discusses under the heading of "preconscious awareness." See Kimberly K. Ferzan, Opaque Recklessness, 91 J. CRIM. L. \& CRIMINOLOGY 597, 629-30 (2001) (noting that vague awareness might be "preconscious in the sense of easily called to mind if attention is focused on it," which means it "remains part of a person's mental states"; observing that the phenomenon often is present "when someone is driving, [such that] many of his actions are part of his preconscious" (internal quotation marks omitted)). 
harm someone. Suppose I don't formulate any thought to the effect that my speeding is likely to harm anyone-perhaps all I think is "boy, this street is sure crowded." Still, if I keep driving down the busy street, no one would dispute that my action was done while possessing actual knowledge that my conduct is virtually certain to harm someone. And this is so even though that particular proposition-my conduct is certain to harm someone-is merely the object of latent knowledge.

Now, the crucial point for present purposes is that Frank's awareness of Bernie's fraud qualifies as latent knowledge in just this sense. After all, according to whatever account of belief possession turns out to be correct, Frank would count as believing that the fraud exists, and this belief is true. For Frank has the dispositions characteristic of believing that the fraud is afoot. If prompted, or even if simply given the opportunity to reflect for a moment, Frank would easily be able to call to consciousness his belief that Bernie is almost certainly engaged in a fraud. Thus, if my belief that I will be penalized for being late to work, or my belief that my speeding is certain to harm a pedestrian, can count as actual knowledge, then Frank's knowledge of Bernie's fraud likewise should count as actual knowledge.

Accordingly, on the reading of the case I am defending, Frank actually knew of the fraud at the time he signed the transfer. It was only the understandable preoccupation with the lives of his family that prevented the knowledge from triggering a motivating reason not to authorize the transfer of funds to Bernie. Consequently, Frank's knowledge was not appropriately connected to his act of approving the transfer for that action to manifest the insufficient regard normally associated with knowingly aiding and abetting a massive fraud. If this reading of the case is right, then we have reason to conclude that mere temporal concurrence between the mens rea of knowledge and the actus reus is not enough to satisfy the connection requirement.

\section{Desideratum 2: How to Sort Cases of Latent Knowledge?}

One upshot of the above discussion is that we will need to formulate the connection requirement for knowledge so as to capture the result that Frank's knowledge of Bernie's fraud is not appropriately connected to his action of approving the transfer. Nonetheless, it is equally clear that in very many cases involving distraction, forgetfulness or latent knowledge generally, the connection requirement will be satisfied. For instance, if the cause of Frank's distraction were merely that he was hungry, or preoccupied by ogling an attractive coworker, it is doubtful that anyone would think the connection requirement unsatisfied. Such cognitive impairments do not appear to be sufficiently extreme or 
egregious to prevent a normal person's knowledge of something as important as the existence of a fraud from being triggered and thus preventing him from aiding that fraud. Therefore, the challenge in formulating the connection requirement for knowledge is to devise a rule that lets us separate (i) cases of latent knowledge, distraction and forgetfulness where the defendant's knowledge is appropriately connected to her conduct from (ii) cases of these kinds where the knowledge is not adequately connected to her conduct. This, then, is the challenge that Desideratum 2 insists that our account of the connection requirement for knowledge should meet.

The same challenge arises, of course, in formulating the connection requirement for recklessness. After all, just as it is possible to have latent knowledge, so too is it possible to possess a very real, but notfully-conscious awareness of the risks that one's conduct imposes on others. For example, the construction foreman might be aware of the risks associated with various methods of blasting in an urban setting (some methods being safer than others) even while not needing to consciously attend to these different risks.

Accordingly, we can construct cases of recklessness that are directly analogous to that of Frank. Just as Frank's knowledge of the fraud was suppressed in a way that made it not sufficiently connected to his conduct, so too can there be cases where the defendant possesses a genuine awareness of a risk of harm, but this awareness is suppressed in a way that prevents the connection requirement from being satisfied. For example, perhaps I am well aware of the dangers that a dish I plan to make for dinner will pose for one of my guests with a nut allergy, but because of a racist slur a stranger hurled at me in the grocery store, I am upset and distracted in a way that prevents my awareness of this risk from being triggered. As a result, I don't act to avoid that risk, as I normally would have. Accordingly, the analogous challenge in formulating the connection requirement for recklessness is to separate (i) those cases of latent (or non-conscious) risk-awareness where the connection requirement is not satisfied from (ii) cases of this type where it is satisfied. This is the challenge that Desideratum 2 demands a solution to for the mens rea of recklessness.

(Although I cannot fully address the issue here, note that Desideratum 2 seems especially important because cases that are structurally similar to latent knowledge can also arise for corporations, not just individuals. ${ }^{78}$ )

78. Suppose a corporation is charged with knowingly having made false statements to a branch of the US government, in violation of 18 U.S.C. $\$ 1001$. An employee of the corporation, Alice, submits a report containing factual 


\section{SIMONS' COUNTERFACTUAL ACCOUNT OF THE CONNECTION REQUIREMENT FOR KNOWLEDGE AND RECKLESSNESS}

With these two desiderata in view, let us consider Simons' attempt to formulate the connection requirement for knowledge and recklessness. ${ }^{79}$ As we will see, the counterfactual approach he offers is a natural proposal, and seems to get many cases right. Nonetheless, this Article contends that it fails precisely because of its counterfactual nature. While I think it would remain useful as a heuristic that might profitably be used by courts or juries (with proper guidance), the drawbacks of the counterfactual approach shown below suggest that a different kind of approach is needed in order to properly understand the workings of the connection requirement. This Part focuses mainly on

errors to some government agency, but she does not know the relevant statements are false. Now consider a different employee, Betty, who has no regular dealings with Alice or her work. Betty happens to pick up a draft of the report left lying in the copy machine. Being knowledgeable about certain aspects of the report's contents, Betty realizes that it contains misstatements. However, she does not know the significance of the report or even that it will be submitted to the government. Accordingly, there is nothing to make Betty suspect she should mention the issues she spotted in the report to any of her colleagues. Still, under respondeat superior principles, knowledge possessed by a corporation's employees in the scope of their employment will be imputed to the corporation. See In re Hellenic Inc., 252 F.3d 391, 395 (5th Cir. 2001) (recognizing that "[a]n agent's knowledge is imputed to the corporation where the agent is acting within the scope of his authority and where the knowledge relates to matters within the scope of that authority"). Accordingly, if Betty's knowledge of the false statements could be proved, it would plausibly be attributed to the corporation. Speaking metaphorically, the corporation thus might be said to possess "latent knowledge" of the false statements in the report. Nonetheless, the connection requirement arguably is not satisfied in this case. After all, Betty's knowledge seems not to be active in producing the conduct that underlies the criminal charges against the corporation-i.e. writing and submitting the report. Thus, there is reason to doubt that criminal liability is appropriately imposed on the corporation in this case. Cf. Kinsey v. Cendant Corp., No. 04 Civ.0582 (RWS), 2004 WL 2591946, at *13 (S.D.N.Y. Nov. 16, 2004) ("It is not enough to establish fraud on the part of a corporation that one corporate officer makes a false statement that another officer knows to be false.").

One might object that criminal liability seems inappropriate here only because respondeat superior principles would not attribute Betty's knowledge to the corporation. Perhaps her knowledge is not within the scope of her employment. I doubt this, but even if it were so, we would still want to know which normative principles explain this aspect of respondeat superior doctrine, and the failure of the connection requirement to be satisfied offers one plausible explanation.

79. See Simons, supra note 9. 
Simons' account of the connection requirement for knowledge. His account can be straightforwardly carried over to recklessness, as can the objections I raise. So to avoid duplication, I concentrate mainly on the case of knowledge.

\section{A. Simons' Account}

Simons begins by suggesting and quickly rejecting a natural firstpass proposal. He notes that perhaps the difficulties concerning latent knowledge might be solved by what he calls a "counterfactual consideration criterion":

if the actor had given the matter a moment's thought, would she have been aware of the relevant risk? And would she then have characterized the risk as likely [as required for knowledge], or as significant [as required for recklessness]? If so, then perhaps the actor should be deemed aware of a likely or significant risk of harm, even if she was not consciously attending to such risks at the time of action. $^{80}$

However, the trouble with this "counterfactual consideration criterion" is that because it more or less tracks the definition of latent knowledge, it would make virtually all cases of latent knowledge, or knowledge from which one was distracted or that one had temporarily forgotten, satisfy the connection requirement. ${ }^{81}$ It would, for example, deem the connection requirement to be satisfied in the case of Frank. After all, it is true of Frank at the time he approves the transfer of funds to Bernie that, if Frank were to give the matter a moment's thought, he would have been able to call to consciousness his knowledge that Bernie was engaged in a fraud. As Simons explains, the present criterion fails because it does not distinguish legitimate from illegitimate explanations for why one did not sufficiently attend to the relevant inculpatory fact (or risk). ${ }^{82}$ Frank's failure to attend to and respond appropriately to his knowledge of Bernie's fraud is understandable and excusable under the circumstances. But this is something to which the present criterion is not sensitive.

Accordingly, Simons suggests a more plausible proposal, which he dubs the "counterfactual risk-avoidance criterion" (or "CRAC," for short). ${ }^{83}$ Under this criterion, "the relevant inquiry is not whether the actor would have been consciously aware of the risk if [s]he had

80. Id. at 253 .

81. Id.

82. $I d$.

83. Id. 
considered the question, but whether, if the actor had brought the knowledge to consciousness, she would have avoided the risk, or instead would have acted the same way." 84 The test that this passage suggests is the following:

$\mathrm{CRAC}_{\mathrm{K}}$ : Let $\mathrm{D}$ be a defendant who performs the actus reus, $\mathrm{A}$, of a crime, $\mathrm{C}$, that requires knowledge that $\mathrm{p}$, but $\mathrm{D}$ has only latent (or otherwise not fully conscious) knowledge that $p$ at the relevant time.

(1) If $\mathrm{D}$ would have done $\mathrm{A}$ even if he had brought this latent knowledge to consciousness, then the connection requirement is satisfied.

(2) But if D would not have done A were his latent knowledge brought to consciousness, then the connection requirement is not satisfied.

Thus, this test asks how the defendant would have behaved were she to have consciously considered the relevant piece of knowledge at the time of acting. It is easy to see how $\mathrm{CRAC}_{\mathrm{K}}$ can be extended to recklessness. ${ }^{85}$

One benefit of $\mathrm{CRAC}_{\mathrm{K}}$ is that, unlike the counterfactual consideration criterion, it suggests a way to distinguish (i) the cases of latent knowledge, distraction and forgetting in which the connection requirement is satisfied from (ii) the cases of these kinds in which it is not. Specifically, if the person with latent knowledge would have acted the same way with fully conscious knowledge, then we may take the connection requirement to be satisfied; otherwise, not. Moreover, $\mathrm{CRAC}_{\mathrm{K}}$ seems to get the case of Frank right. After all, it was stipulated that if Frank had not been distracted, but had been in a position to attend to his knowledge of Bernie's fraud, he would not have done the act that aided Bernie's fraud. Accordingly, $\mathrm{CRAC}_{\mathrm{K}}$ correctly takes the connection requirement to be unsatisfied in the case of Frank. Thus, $\mathrm{CRAC}_{\mathrm{K}}$ might seem to do an adequate job of satisfying Desideratum $2{ }^{86}$

84. See Simons, supra note 9 , at 253.

85. Here is the test as applied to recklessness:

$\mathrm{CRAC}_{\mathrm{R}}$ : Let $\mathrm{D}$ be a defendant who performs the actus reus, A, of a recklessness crime that requires awareness of a substantial and unjustified risk that $p$, but $D$ has only a latent awareness of such a risk that $p$.

(1) If $\mathrm{D}$ would have done $\mathrm{A}$ had he brought his awareness of the risk that $\mathrm{p}$ to consciousness, then the connection requirement is satisfied, and D may be punished accordingly.

(2) But if D would not have done A were the latent awareness of the risk that $\mathrm{p}$ brought to consciousness, then the connection requirement is not satisfied.

86. Likewise for the corporate case, discussed supra note 78. Insofar as Alice would not have submitted the report to the government if made aware of Betty's 


\section{B. An Initial Problem}

However, an obvious problem $\mathrm{CRAC}_{\mathrm{K}}$ encounters right away is that it seems not to satisfy Desideratum 1 . That is, it offers little explanation of what it might mean for knowledge of some fact to be active in producing a particular bit of knowing misconduct. To see this, suppose the proposed test is satisfied: $D$ possesses latent knowledge of the requisite fact, $\mathrm{p}$, at the time he does $\mathrm{A}$, and, moreover, $\mathrm{D}$ would have acted the same way even if fully conscious of this knowledge. Nonetheless, this does not guarantee that D's latent knowledge that $\mathrm{p}$ was actually involved in producing (or actuating) D's conduct.

Consider a variation of the case of Frank-Bad Frank. Like Frank, Bad Frank is distracted from his knowledge of Bernie's fraud upon receiving news that his family has been in a bad car accident. The only difference is that in this case, Bad Frank would have gone on to approve the transfer of his clients' funds to Bernie even if he consciously attended to his knowledge of the fraud. Thus, Bad Frank's knowledge in the present case seems to be no more active in producing his conduct than this knowledge was in the original version of the case, where the connection requirement was not satisfied. Accordingly, like Frank, Bad Frank's knowledge does not seem to be appropriately connected to his conduct. The causal contribution Bad Frank's knowledge would have made to his actions was blocked by the overwhelmingly distracting news of his family's car accident. Thus, satisfying the counterfactual test offered by $\mathrm{CRAC}_{\mathrm{K}}$ does not guarantee that an actor's knowledge was appropriately connected to his conduct.

The fact that $\mathrm{CRAC}_{\mathrm{K}}$ does not capture what it means for knowledge to be active in producing a particular bit of conduct is a significant drawback. It amounts to abandoning the attempt to satisfy Desideratum 1 .

However, perhaps the ambitions of Simons' account are different. In particular, $\mathrm{CRAC}_{\mathrm{K}}$ might be construed as an attempt to offer a test for when a particular actor with latent knowledge is just as culpable as someone who acts analogously with fully conscious knowledge, in which case the person with merely latent knowledge could plausibly be punished as an actor who uncontroversially acts knowingly. ${ }^{87}$ Thus

knowledge of the false statements it contained, Betty's knowledge would not be appropriately connected to the act of submitting the report under Simons' test.

87. This would make latent knowledge function in the same way as willful ignorance. The "traditional rationale" for allowing willful ignorance to be treated as a substitute for actual knowledge is that acting in willful ignorance is supposed to be just as culpable as acting knowingly. See Global-Tech Appliances, Inc. v. SEB S.A., 131 S. Ct. 2060, 2069 (2011); United States v. 
interpreted, the suggestion is that we can make do in the criminal law without an account that satisfies Desideratum 1 -i.e. without an answer to the theoretical question of what is involved in a piece of knowledge actuating a piece of conduct. Fully stated, then, $\mathrm{CRAC}_{\mathrm{K}}$ as a culpability test ("CRAC $\mathrm{K}_{\mathrm{K}} \mathrm{CT}$ ") amounts to this:

CRAC $_{K}$ CT: Let $D$ be a defendant who performs the actus reus, A, of a crime, $\mathrm{C}$, that requires knowledge that $\mathrm{p}$, but $\mathrm{D}$ has only latent (or otherwise not fully conscious) knowledge that $\mathrm{p}$.

(1) If D would have done A even if he had brought this latent knowledge to consciousness, then $\mathrm{D}$ is just as culpable as someone who does $\mathrm{A}$ with fully conscious knowledge that $\mathrm{p}$ (i.e. as in a paradigmatic case of doing $\mathrm{C}$ knowingly). Hence, $\mathrm{D}$ can be punished accordingly.

(2) But if D would not have done A were his latent knowledge brought to consciousness, then $\mathrm{D}$ is not as culpable as someone who does $\mathrm{C}$ with fully conscious knowledge that $\mathrm{p}$.

At best, this account attempts to satisfy Desideratum 2, while suggesting that we can make do without an answer to the challenge in Desideratum 1. (As before, it's easy to see how this test can be carried over to recklessness. ${ }^{88}$ )

\section{The Problem with $C R A C_{K}$ as a Culpability Test}

CRAC $_{\mathrm{K}} \mathrm{CT}$ is also deeply problematic. Most importantly, it permits treating defendants who in fact did not consciously attend to their knowledge as if they had done so. That is, $\mathrm{CRAC}_{\mathrm{K}} \mathrm{CT}$ allows us to take the former group of defendants to be just as culpable as the latter group, solely on the basis of how the former would have behaved under non-actual circumstances. Thus, it ties the amount of culpability attributed to these defendants not to the type of mental state they actually acted with (i.e. latent or otherwise not fully conscious knowledge), but rather to how they would have behaved if they had possessed a somewhat different mental state while acting (i.e. fully conscious knowledge). In effect, then, $\mathrm{CRAC}_{\mathrm{K}} \mathrm{CT}$ holds agents responsible for how they are willing to act, not on the basis of the nature of their actual mental states and conduct.

But this is not the usual way of the criminal law. The criminal law requires culpability attributions, and the resulting imposition of

Jewell, 532 F.2d 697, 700 (9th Cir. 1976) (en banc). See also, Sarch supra note 56 , at 5 .

88. Cf. supra note 85 and accompanying text. 
punishment, to be tied to the nature of one's actual conduct and mental states-not how one would have behaved under non-actual circumstances. $^{89}$ After all, were it to do otherwise, the criminal law would be attributing culpability and imposing corresponding punishments merely on the basis of bad character. ${ }^{90}$ As Simons himself explains:

one very important rationale for requiring an appropriate connection between mental states and acts is to avoid punishing individuals simply because they display a "bad character." On this view, the harsh sanctions of the criminal law should not be brought to bear on individuals who have not yet done anything wrong, but who merely have disreputable - or even dangerous - character traits. ....We are similarly, and properly, reluctant to impose punishment on a person simply for [attitudes or characteristics] unless and until [they] are expressed in action. ${ }^{91}$

For ease of reference, call the principle Simons expresses in the last sentence of this passage the "punishment for actual attitudes principle," or "PAAP" for short. It clearly runs afoul of this principle to punish a person who does actus reus A with merely latent knowledge as if she did A with fully conscious knowledge, since it is only the former mental state, not the latter, that can be productive of or expressed in her actual conduct.

To this, one might object that if prong (1) of $\mathrm{CRAC}_{\mathrm{K}} \mathrm{CT}$ is satisfied, then we can safely make an exception to PAAP. After all, if we are quite sure that someone who does A with merely latent (or otherwise not fully conscious) knowledge would act the same way were she to consciously attend to that knowledge, then it might seem we can be confident that she is just as culpable as someone who does A with fully conscious knowledge. Consider the argument behind this objection in more detail. To give it a name (an admittedly tendentious one), call it the seductive argument. In general, performing the actus reus, A, with knowledge of the inculpatory proposition, $p$, is culpable because it shows one to be insufficiently concerned with avoiding the harm caused by $\mathrm{A}$ or

89. Cf. Simons, supra note 9 , at 233-34.

90. See, e.g., Michelson v. United States, 335 U.S. 469, 489 (1948) (Rutledge, $\mathrm{J}$., dissenting) ("Our whole tradition is that a man can be punished by criminal sanctions only for specific acts defined beforehand to be criminal, not for general misconduct or bearing a reputation for such misconduct."); WAYNE LAFAVE, 1 SubTantive CRIMINal Law $\S 6.1$ (2d ed. 2014) ("One basic premise of Anglo-American criminal law is that no crime can be committed by bad thoughts alone.").

91. Simons, supra note 9, at 233-34 (emphasis added). 
the other bad-making features of A. Since $p$ is the inculpatory proposition for the crime of which $A$ is the actus reus, knowing that $p$ should give one a motivating reason not to perform $A$-it should motivationally repel one from A. But if one proceeds to do A anyway (and lacks any adequate excuse or justification for doing so), then this shows one to be insufficiently concerned with the reasons against performing A (i.e. insufficiently repelled by A's bad-making features). As Simons correctly notes, "[i]f a person acts despite his belief that he is likely to cause harm ... (or ... despite his belief that an inculpatory circumstance is likely ...), then his culpability arises from his failure to give sufficient weight to that consideration in his conduct." ${ }^{92}$ Now consider how things stand when prong (1) of $C R A C_{K} C T$ is satisfied. If there is sufficient evidence that the defendant with merely latent knowledge would behave the same way even with fully conscious knowledge, then, the present argument goes, this tells us something about her degree of insufficient concern for those who will be adversely affected by her conduct. On the basis of this evidence, we might conclude that she has just as much insufficient concern for the protected interests of others as a similarly situated defendant with fully conscious knowledge. Accordingly, the seductive argument supposes, she is just as culpable as a similarly situated defendant with fully conscious knowledge. As a result, it might seem there is nothing problematic about departing from PAAP in such a case, and holding the defendant to account not for her actual mental state of latent knowledge, but for the mental state we know she would be willing to act with.

However, the seductive argument fails. It conflates the culpability of one's character (i.e. one's general level of concern for the protected interests of others) with one's culpability for a particular action (i.e. the extent to which that action manifests insufficient regard for others). To see the importance of this distinction, recall Bill, who we know intended to kill his uncle, but in fact caused his uncle's death only negligently. ${ }^{93}$ Because we know that Bill intended to kill his uncle, and indeed are quite sure that he would have killed him intentionally had he gotten the chance, it follows that we know Bill has a highly deplorable character. Nonetheless, this does not provide the basis for taking Bill's conduct to be as culpable as intentional murder, and for punishing him accordingly. The seductive argument, however, collapses this distinction and would take Bill to be punishable as an intentional murderer because of what we know about the badness of his character-i.e. because of what we know he would do. The seductive argument goes wrong because it would have

92. Id. at 249-50.

93. See supra notes $35-36$ and accompanying text. 
us punish a person who does A with some mental state M1 (e.g. recklessness, merely latent knowledge, etc.) as if he did $\mathrm{A}$ while possessing a more culpable mental state M2 (e.g. fully conscious knowledge, intent, etc.)-which amounts to making an exception to PAAP - simply because we are confident that this person would have done A with M2, too. Such a position implausibly entails that Bill could be punished for intentional murder.

The reason Bill's actual conduct does not support a conviction for intentional murder, although we know he intended to commit murder and has a character as deplorable as that of a murderer, is that Bill's actually only negligent conduct did not manifest the amount of insufficient regard-and thus culpability - that characterizes intentional murder. ${ }^{94}$ But what is it for an action to manifest a given amount of insufficient regard? Let me clarify this crucial concept of manifestation. Grant that what matters to criminal punishment is not the badness of one's character directly, but rather culpability for one's actual conduct. Moreover, grant that one's culpability for a particular action corresponds to the amount of insufficient regard for the protected interests of others that that action manifests. The question remains: how do we determine how much insufficient regard a given action manifests?

The proposal I am sympathetic to draws on a view recently suggested by Gideon Yaffe. ${ }^{95}$ The basic idea is to apply a principle of lenity when determining how much insufficient regard a particular action manifests, and thus how culpable one is for it. ${ }^{96}$ Suppose that for any bad or wrong action, A, we can identify the minimum amount of

94. The criminal law thus seems to embody the following principle: The amount of culpability the criminal law may treat a defendant as having (and use as the basis for fixing the amount of punishment he deserves) equals the amount of culpability manifested in the conduct he actually performed and for which he was convicted (where culpability is presently being understood as insufficient regard for the protected interest of others).

95. See Gideon Yaffe, The Point of Mens Rea: The Case of Willful Ignorance 22 (July 30, 2014) (unpublished manuscript) (on file with author). Thomas Aquinas also endorsed a principle of this sort: "unless we have evident indications of a person's wickedness, we ought to deem him good, by interpreting for the best whatever is doubtful about him." THOMAS AQUINAS, Summa THeOLoGicA, pt. 2, Q.60 art. 4, at 151 (Fathers of the English Dominican Province trans., R. \& T. Washbourne, Ltd. 1918) (1274). Aquinas's argument for this principle is that "from the very fact that a man thinks ill of another without sufficient cause, he injures and despises him," and "no man ought to despise or in any way injure another man without urgent cause." Id. Accordingly, he concludes, we ought to apply a principle of lenity when attributing blame to actors for their conduct.

96. Cf. Yaffe, supra note 95 , at 22 (discussing a related principle of lenity). 
insufficient regard for the protected interests of others (i.e. ill will) that would be needed to perform $A$ in the actual circumstances of A's performance. The relevant principle of lenity, then, dictates that we may take $A$ to manifest only this minimum required amount of insufficient regard for others, and no more. ${ }^{97}$ Accordingly, even if we know that Bill has an utterly deplorable character, and his ill will towards his uncle is bottomless, if we would only need to posit the amount of insufficient regard that is normally associated with a merely negligent actor in order to explain Bill's actual conduct under the circumstances, then it is only this minimum amount of insufficient regard that we'd be permitted-by the principle of lenity - to take his actual conduct to manifest. ${ }^{98}$

97. One might wonder what motivates this principle of lenity. While I can't offer a full justification of it here, let me suggest a few possible ways to explain its appeal. First, one might think that this principle of lenity is an appropriate expression of generosity on the part of the moral community (i.e. the state) or its members. Insofar as generosity or charity is a virtue that states and individuals should display-especially in morally charged activities like attributing culpability to others - then this would provide some normative support for the principle of lenity suggested in the text.

Second, perhaps this principle of lenity can be justified on more cynical, pragmatic grounds. One might think that a wise ruler-on the model of Machiavelli's prince-would do well to only punish his subjects to the extent that he absolutely must in order to remain credible. Thus, the wise ruler would not punish his subjects more harshly than is demanded by the minimum amount of culpability required to explain their actions. Insofar as our blaming practices generally have come to embody this wisdom as well, this would explain why we are inclined to see a given piece of conduct only as manifesting the minimum amount of ill will towards others that is necessary to posit in order to explain the performance of that action under the circumstances. This, then, is a second route to the principle of lenity described in the text.

98. Simons, too, recognizes something like this principle of lenity. But, problematically, he cashes it out in terms of what we normally can infer from the defendant's conduct and mental state. He writes:

But why is the reckless actor less culpable than the knowing actor? One explanation is this: we ordinarily cannot be confident that the reckless actor would have created the risk of a deadly harm, or taken the risk of transporting the package, if she knew that the harm was likely to occur or that the package was likely to contain cocaine. (...) [I]t cannot be assumed that the inadvertent actor would have acted as the advertent (reckless) one did, or that the reckless actor would have acted as the knowing one did. Normally, it is more accurate to assume the contrary, that he would not have so acted.

Simons, supra note 9, at 254-55. This is problematic because in some cases we know that what we normally can assume or infer about the defendant's culpability just does not hold. This is clearly illustrated by, for example, the case of Bill. There we know that Bill would have intentionally killed his uncle if given the chance. So Simons' proposal, too, seems to implausibly entail that Bill can be punished as an intentional murderer. 
Now apply this framework to $\mathrm{CRAC}_{\mathrm{K}} \mathrm{CT}$ 's proposed solution to the problem of latent knowledge. If we know that the actor with merely latent (or not-fully conscious) knowledge would have performed the actus reus anyway even if he had consciously attended to this knowledge, this at best allows us to conclude that this actor's character is as bad as someone who performs the actus reus with fully conscious knowledge. But it does not automatically follow that his actual conduct, which involved less-than-fully conscious knowledge, manifests as much insufficient regard-and thus culpability - as the same actus reus done with fully conscious knowledge would. After all, the amount of insufficient regard manifested by an act performed with not fully conscious knowledge equals the minimum amount of insufficient regard needed, under the circumstances, to generate that particular conduct. And this will vary heavily depending on the circumstances of the case. In particular, it will depend on things like: (i) the explanation of why the defendant did not consciously attend to the relevant piece of knowledge, (ii) whether it would be reasonable to expect someone like the defendant to consciously attend to it in a case like this, (iii) whether a normal person would be able to give due weight to the relevant knowledge even without bringing it to consciousness, and so on. For example, it might not be reasonable to expect someone in Frank's situation to recall his knowledge of the fraud and be able to respond to it properly under the extreme circumstances of that case. Accordingly, we would not need to posit very much insufficient regard for the interests of others in order to explain Frank's approval of the transfer here. ${ }^{99}$

The upshot is that while $\mathrm{CRAC}_{\mathrm{K}} \mathrm{CT}$-particularly prong (1)plausibly identifies conditions under which the defendant with merely latent knowledge has a character that is just as bad as a similarly situated actor with fully conscious knowledge, prong (1) does not tell us when the defendant's actual conduct manifests as much insufficient regard as the same conduct performed with fully conscious knowledge. For this reason, the case of Bad Frank threatens to make trouble for the present account. Bad Frank was stipulated to be such that, even if he were to bring his knowledge of Bernie's fraud to consciousness, he still would

99. This explains why the criminal law rejects the idea of holding people accountable on the basis merely of how they would have behaved under counterfactual circumstances. It requires that the culpability attributed to the defendant, and thus the punishment he is given, be tied to the mental states he actually had when acting. This, in turn, is because criminal punishment is premised on the amount of culpability manifested in one's actual conduct, not on the culpability of one's character (which is all that facts about what one would do under other counterfactual circumstances directly speaks to). 
have gone ahead and approved the transfer of funds to Bernie. While this plausibly shows that Bad Frank's character is just as contemptible as someone who knowingly aids a massive fraud, it is far from obvious that Bad Frank is just as culpable for his conduct as the analogous action performed in full conscious awareness of the fraud. Given that Bad Frank in fact was understandably distracted from his culpable knowledge at the time of acting, it is doubtful that this knowledge was active in producing his actual conduct. Thus, it is doubtful that his actual conduct manifested more culpability than the same act done only negligently would have. While we know Bad Frank was willing to go so far as to knowingly aid Bernie's fraud, in fact he did not go this far. His knowledge of Bernie's fraud was understandably blocked or screened off from playing the role in his deliberations and actions that it normally would have. (This is admittedly a piece of moral luck, occasioned by his being reasonably distracted from his knowledge of Bernie's fraud.) Accordingly, CRAC $\mathrm{C}_{\mathrm{K}} \mathrm{CT}$ is in trouble because it entails that Bad Frank's actual conduct is just as culpable as knowingly aiding a massive fraud, even though his conduct, given the distracted state he was in, does not actually manifest this level of insufficient regard for others.

\section{A Weaker Proposal}

Simons seems to recognize that there is something problematic about the present account: He acknowledges that it is "much more controversial" to go along with prong (1) of CRAC $\mathrm{K}_{\mathrm{K}} \mathrm{CT}$ and impose a heightened punishment on the defendant in virtue of a mental state he did not actually act with, but would have been willing to act with. ${ }^{100}$ Accordingly, Simons raises the idea of backing off of prong (1), and instead insisting only on prong (2). ${ }^{101}$ Instead of claiming that the defendant's willingness to perform the actus reus even with fully conscious knowledge is sufficient for the level of culpability that the defendant would have if the connection requirement were satisfied, we should in fact only take this willingness on the defendant's part to be a necessary condition for having this level of culpability. Thus, prong (2) would just identify one circumstance under which we can treat the connection requirement as not being satisfied. Specifically, if we are confident that the defendant would not have done the actus reus, A, were his latent knowledge brought to consciousness, then we cannot treat him as precisely as culpable as someone who does A while fully conscious of the relevant knowledge.

100. See Simons, supra note 9, at 255.

101. Id. 
However, this weaker position is also problematic. For one thing, counterexamples loom. Some defendants with latent knowledge intuitively can be just as culpable as similarly situated actors with fully conscious knowledge, even though these defendants would not perform the relevant act with fully conscious knowledge. Consider yet another variation of the case of Frank. This variation involves Phil, who is almost exactly like Frank: He, too, came to know of Bernie's fraud the same morning. But whereas Frank was distracted from this knowledge by hearing of his family's accident, Phil is distracted from his knowledge of Bernie's fraud because he is given to ogling an attractive coworker across the hall. Because of his distracted state, Phil has only latent knowledge of Bernie's fraud, and in his distraction, he authorizes a transfer of funds to Bernie. Nonetheless, suppose that if Phil's knowledge had been fully conscious, he would not have transferred the funds to Bernie. I submit that, under these circumstances, Phil is just as culpable for authorizing the transfer with latent knowledge of the fraud as it would have been to do the same act with fully conscious knowledge. Thus, prong (2) seems to face problems because some reasons for one's knowledge being only latent do not seem to reduce one's culpability for how one acts while in this mental state.

One might object that Phil seems just as culpable as a similarly situated actor with fully conscious knowledge only because the independent culpability of ogling a coworker is added to the culpability of aiding a fraud negligently, but combining distinct sources of culpability in this way is illicit. However, the above case does not involve adding together separate quantities of culpability. Instead, the counterexample is meant to appeal only to the culpability inherent in Phil's act of approving the transfer with latent knowledge of the fraud, where one salient feature of this act is that Phil did it only because he was distracted by ogling his co-worker. Phil's behavior suggests that he is more concerned with getting the pleasure of staring at someone's body than with the victims of the fraud he is latently aware of. Even if Phil would not normally approve the transfer, his action demonstrates that, at least on this occasion, he values his own sexual gratification more highly than the interests of the victims of the fraud. Had he been sufficiently concerned with those interests, he would have approached his work with greater care and not allowed a trivial distraction to interfere with the need to avoid transfers to fraudulent investment managers. Accordingly, the above case appeals only to the insufficient regard manifested in Phil's action and does not require cobbling together quantities of culpability from different sources.

If this is right, the case of Phil suggests that a defendant's willingness to perform the actus reus even with fully conscious 
knowledge is not necessary for him to be as culpable as a similarly situated actor with fully conscious knowledge. Accordingly, prong (2) appears dubious. (Other cases seem to support the same conclusion. ${ }^{102}$ )

In addition to this difficulty, it is important to recall the costs for the present account in giving up on any attempt to satisfy Desideratum 1. Since CRAC $_{K}$ CT initially set forth both necessary and sufficient conditions for the actor with latent knowledge to be precisely as culpable as the comparable actor with fully conscious knowledge, it amounted to a test for equal culpability that would allow us to make do without any explanation of what is involved in a piece of knowledge actuating one's conduct. But once the account is weakened to include only the necessary condition-i.e. only prong (2) of $\mathrm{CRAC}_{\mathrm{K}} \mathrm{CT}$-we no longer have a test for equal culpability. Even if the necessary condition is satisfied, the question of whether the defendant with latent knowledge can be punished as a full-fledged knowing criminal remains open. Thus, prong (2) by itself does not amount to a workable approach to the issues surrounding latent knowledge and the connection requirement in general. It leaves important questions about the nature of knowing misconduct unanswered and fails to explain how acting from latent knowledge works or why it is culpable.

Accordingly, it is reasonable to ask whether we can do better. It would clearly be more satisfying for our account to both explain what it means for knowledge to be active in producing conduct-i.e. satisfy Desideratum 1 -as well as explain how latent knowledge can produce

102. It seems there can be defendants who are just as culpable as analogous actors with fully conscious knowledge even though these defendants can only bring themselves to perform the actus reus with latent knowledge, and would not perform it if the relevant knowledge were made fully conscious. Consider someone who possesses latent knowledge of an inculpatory proposition, but if he were to bring this knowledge to consciousness-were it vividly present in his mind-he would not be able to go through with the actus reus he is planning. Sensing this about himself, he avoids thinking about the inculpatory proposition he latently knows to be true. Perhaps he plays loud Wagner music on his iPod to push all unpleasant thoughts from his mind. By doing so, he enables himself to go through with the contemplated conduct. Such a person plausibly would be just as culpable as someone who acts the same way with fully conscious knowledge of the inculpatory proposition, and this is so even though he would not do the actus reus if his latent knowledge were fully brought to consciousness. His conduct seems to manifest at least as much insufficient regard as that of the full-fledged knowing actor. This, in turn, is because he adopted a strategy of self-management to enable him to get around his limitations-i.e. his inability to go through with the crime if his latent knowledge were brought to consciousness. Thus, we seem to have a different sort of counter-example to prong (2). 
and affect the culpability of one's conduct-i.e. satisfy Desideratum 2 . The account of the connection requirement I will offer in the next Part aims to do just this. As a result, it remedies the defects of $C_{R A C} C T$.

\section{A NON-COUNTERFACTUAL ACCOUNT OF THE CONNECTION REQUIREMENT FOR KNOWLEDGE AND RECKLESSNESS}

\section{A. Presenting the Account}

The problems with Simons' proposal largely stem from its use of a counterfactual test. By contrast, the account defended in this Part places normative questions, not a counterfactual inquiry, at the heart of the procedure for determining whether the connection requirement is satisfied. To work up to the account, I consider in detail a paradigmatic case in which the connection requirement for knowledge is satisfied. The case involves fully conscious knowledge, rather than latent knowledge, distraction or the like. Once we understand how the connection requirement works in the paradigmatic case, we can apply the resulting approach to cases involving less-than-fully-conscious knowledge.

Here, then, is a paradigmatic case in which the actor's knowledge is appropriately connected to his conduct to make him guilty of a knowledge crime. In some jurisdictions, if one lights a building on fire knowing that another person is inside, this suffices for being guilty of a higher grade of arson. ${ }^{103}$ Thus, consider David, who lights a building on fire while fully aware of the fact that another person is currently inside. He sees the person inside the building with his own eyes, and even thinks to himself, "What do you know, there's someone in there." To make this a case of a pure knowledge crime, suppose that David does not desire or intend the death of the person in the building. David's purpose in setting the fire is just to collect the insurance on the building. Thus, David is merely insufficiently concerned with the well-being of the person inside the building. In such a case, it should be uncontroversial that the connection requirement is satisfied. Hence, David is guilty of the higher grade of arson.

As I'll now go on to explain, such a paradigm case of knowing misconduct involves three main features. First, David performs the actus

103. See, e.g., N.Y. PENAL LAW $\S 150.15$ ("A person is guilty of arson in the second degree when he intentionally damages a building or motor vehicle by starting a fire, and when (a) another person who is not a participant in the crime is present in such building or motor vehicle at the time, and (b) the defendant knows that fact or the circumstances are such as to render the presence of such a person therein a reasonable possibility.") (emphasis added). 
reus of the crime (i.e. lighting the building on fire) for some motivating reason or other (perhaps several). As before, ${ }^{104}$ let us suppose that this reason, $\mathrm{R} 1$, consists of the set of desires and instrumental beliefs that together rationalize this action, and which (non-deviantly) causes this action in virtue of rationalizing it. ${ }^{105}$

Now recall the puzzle behind Desideratum $1 .{ }^{106}$ It might appear odd that the knowledge at issue in this case-i.e. that someone is inside the building-does not figure into the reason for which David lit the fire-i.e. R1. How, then, can this piece of knowledge be active in producing this action, or connected to it in a way that allows this knowledge to be part of what determines the amount of culpability the action manifests? How can a particular belief (one's practical certainty of a fact or awareness of a substantial risk) be active in producing a particular action even if it does not directly figure into the reason for which the action was performed?

The second feature of the paradigm case provides the answer. In this case, it is fair to expect that David's knowledge of the person's presence in the building should trigger a motivating reason, R2, against lighting the building on fire that has a strength sufficient to outweigh R1 (plus whatever other motivating reasons he might have for the action), but it does not. In other words, if we were dealing with a normal lawabiding person, the knowledge of a person's presence within the building would combine with another desire held by the actor to avoid causing unjustifiable harm to others, and this would give the actor a sufficient motivating reason not to light the building on fire. This is reason R2. Because David actually proceeds to light the building on fire, we know that he either lacked R2 altogether or that R2 did not have a sufficient strength to outweigh R1.

Accordingly, David's knowledge that a person was in the building is appropriately included as part of the causal explanation of his act of lighting the fire. In particular, it is an instance of causation by the lack of contrary reasons. Here I am following Arpaly and Schroeder. ${ }^{107}$ In particular, I am basing my account on their discussion of how the lack of

104. See supra note 48 and accompanying text.

105. See Arpaly and Schroeder, supra note 42 . In their view, "[t]o think or act for a reason is for the event of one's thinking or acting to be caused (or appropriately causally explained) by one's other attitudes in virtue of the fact that these attitudes [i.e. their contents] rationalize (to some extent) the thought or action." (emphasis omitted). Id. at 62.

106. See supra Part I.

107. See Arpaly and Schroeder, supra note 42 , at $82-83$. 
rationalizing reasons can be causally efficacious in producing an action. Here is their very insightful explanation of the phenomenon:

For an action to be caused by, or appropriately explained by, a set of attitudes it is not necessary that these attitudes contribute a causal "oomph" to the action. There is a role in (some) accounts of causation, and in (some) accounts of scientifically acceptable explanation, for events that occur in part because other events do not occur. .... There seem to be a wide range of cases in which causal explanation by appeal to absences is correct or appropriate. And some of these cases are found in the mental realm. If there had been a fire truck parked in the intersection on Travis's left he would not have turned left. The absence of a strong rationalization not to turn left plays a causal role in the bringing about of Travis's left turn. The absence of a strong rationalization is not itself providing 'oomph' to the process, is not doing work in the technical sense proper to physics, but it is part of the causal or explanatory picture nonetheless. ${ }^{108}$

Now apply this idea to David. Given his knowledge, David reasonably should have had motivating reason $\mathrm{R} 2$ and it should have outweighed R1, but it did not. Accordingly, his lack of R2 under circumstances where we can legitimately expect him to possess it is a salient part of - something worth mentioning in - the causal explanation of his act of lighting the building on fire. ${ }^{109}$ This, then, indicates how to understand LaFave's talk of a mens rea "actuating" a piece of conduct when this mens rea is knowledge. ${ }^{110}$ A piece of knowledge is involved in "actuating" a bit of conduct if the knowledge could have been expected to trigger this countervailing reason $\mathrm{R} 2$ with sufficient strength, but in fact it did not. ${ }^{111}$ Accordingly, we have an explanation of how

108. Id.

109. My account thus commits me to saying that what information is appropriately included in the causal explanation of an action can depend on normative considerations and considerations about what information strikes us as salient or worth mentioning.

110. See supra note 13.

111. This also makes sense of the similar claims Dressler makes about the requirement of "motivational concurrence"-i.e. that " $t]$ he defendant's conduct that caused the social harm must have been set into motion or impelled by the thought process that constituted the mens rea of the offense." Dressler, supra note 8, at 199 (emphasis added). Cf. supra note 46. 
knowledge might actuate or be active in producing action, thus satisfying Desideratum $1 .^{112}$

The fact that David's knowledge is in this sense active in producing his conduct also has implications about the culpability of this conduct. In particular, the failure of David's knowledge to trigger a sufficiently strong countervailing reason, $\mathrm{R} 2$, is a legitimate part of the basis for determining how culpable David is for starting the fire (i.e. how much insufficient regard for others it manifests). It is because David's knowledge that there is a person in the building did not trigger a motivating reason of a sufficient strength against starting the fire that his conduct manifests a serious amount of insufficient regard for others. More precisely, it manifests substantially more insufficient regard than it would have were he unaware that someone was in the building.

There is one more wrinkle that the account must accommodate. In particular, the knowledge that a person is in the building cannot always be expected to give one a countervailing reason like R2 against lighting the building on fire. For example, one might be in circumstances that make it reasonable not to remember that there was a person in the building, or one might have been distracted for understandable reasons, or one might have been debilitatingly fatigued, or involuntarily drugged, or in a state of shock, etc. Accordingly, in order for one's lack of R2 to have been part of the causal explanation of what produced one's action of lighting the building on fire, one had to have been in conditions that normally can be expected, both statistically and normatively, to trigger this countervailing reason $R 2$ with sufficient strength. If one is reasonably distracted, understandably forgetful, involuntarily intoxicated, in a state of shock, or the like, then one's failure to possess R2 with sufficient strength would not appear to be a salient part of the causal explanation of one's act of lighting the building on fire. As a result, the connection requirement would not be satisfied and one would not count

112. One might worry that this feature of my account simply makes it covertly rely on counterfactual considerations, thus rendering it illicit in just the way I argued Simons' account was problematically counterfactual. Nonetheless, my account is not counterfactual in a problematic way. The reason is that according to my account, we are not asked to evaluate one's culpability based on how one would have acted under non-actual circumstances (i.e. if one had had a different mental state). Rather, my test asks us to evaluate one's culpability based on one's actual mental state and attitudes-in particular, one's lack of certain motivating reasons against the misconduct in question, which one should have had, but did not. That is why I reject the claim that my account is counterfactual in any illicit way. It assigns culpability based on one's actual configuration of mental states. 
as guilty of a knowledge crime (i.e. would not be as culpable as a truly knowing wrongdoer).

Of course, no excusing conditions of this sort exist in David's case, since he is a paradigmatic instance of someone who does act knowingly. Thus, the third core feature of the paradigmatic case is the lack of any circumstances that might excuse the failure of the actor's knowledge to trigger a countervailing motivating reason, R2, with sufficient strength. Consequently, the important take-away is that our account of the connection requirement must accommodate the possibility of such excusing conditions.

Obviously, there can be disagreement about what the circumstances are in which knowledge that someone is in the building can be expected to trigger a reason like $\mathrm{R} 2$ against lighting the building on fire. But at a minimum, it would not be plausible, I think, for the law to take gardenvariety distraction or forgetfulness to be enough to prevent the connection requirement from being satisfied. The reason is that normal people are sufficiently aware and competent that merely being distracted by an event that is not especially out of the ordinary typically will not be enough to prevent the belief (even the latent belief) that a person is inside the building from triggering the relevant countervailing reason against lighting the building on fire. To adopt this rule would be to rely on normative assumptions about when the belief that someone is in the building can reasonably be expected to trigger a motivating reason like R2 against lighting the building on fire.

Accordingly, we see how normative considerations can impact whether a given piece of knowledge is adequately connected to the relevant actus reus. If the knowledge can be expected (normatively, based on our best statistical understanding of how normal people function cognitively) to give a law-abiding person a decisive motivating reason against performing the actus reus, but it actually did not give the defendant this reason, then his knowledge and the absence of the relevant countervailing reason against the actus reus are a salient part of the causal explanation of the defendant's performance of that actus reus. But if the relevant knowledge cannot be expected to produce this reason, then the presence of his knowledge and the absence of the countervailing reason against the actus reus would not be a salient part of the causal explanation of that action. In that case, the connection requirement would not be satisfied. In this way, the question of whether the connection requirement is satisfied in any given case will be highly dependent on what motivating reasons the relevant piece of knowledge can be expected to trigger for a law-abiding person in the defendant's circumstances. 
Having identified the three core features of the paradigmatic case in which the connection requirement for knowledge is satisfied, we can abstract from the particulars of David's case to get a general account of the connection requirement. Thus, we get:

Connection Requirement for Knowledge: D's knowledge, $\mathrm{K}$, that inculpatory proposition $\mathrm{p}$ is true (where $\mathrm{p}$ is the proposition e.g. that one's conduct will cause a bad result or that some attendant circumstance obtains) is appropriately connected to (causally efficacious in producing) D's performance of the actus reus, $\mathrm{A}$, of a crime requiring knowledge that $p$ if and only if:

(1) $\mathrm{D}$ possesses $\mathrm{K}$ at least latently during the relevant part of his performance of $\mathrm{A}$,

(2) while A'ing (or the relevant part of it) D is in conditions (cognitive, situational, etc.) where we would expect $\mathrm{K}$ to give a law abiding person in D's situation a decisive (overriding) motivating reason not to do A (i.e. to do something besides $\mathrm{A}$ that would not impose the harm associated with $p$ ), and

(3) $\mathrm{K}$ did not actually give $\mathrm{D}$ a motivating reason against $\mathrm{A}$ of a sufficient strength to get him to refrain from doing $\mathrm{A}$ (i.e. $\mathrm{D}$ did A anyway).

When these three conditions are satisfied, we would be permitted to say that defendant D did A "despite" his knowledge that $p$. In that case, the connection requirement between knowledge and actus reus is satisfied.

Moreover, when these three conditions obtain, the piece of knowledge in question can fairly be treated as part of the basis for determining how much culpability action A manifests. The thought here is that $\mathrm{K}$ should give $\mathrm{D}$ a motivating reason not to do A because $\mathrm{D}$ should have sufficient regard for the protected interests of others. Because $\mathrm{K}$ does not trigger such a motivating reason of a sufficient strength, despite D's being in conditions where we would expect it to, we must suppose that D's regard for others is insufficient to a substantial degree in order to explain his performance of A. Thus, his act A would manifest a substantial amount of insufficient regard.

This account of the connection requirement for knowledge is useful, not only because it captures the paradigm case of knowing misconduct, but also because it entails several sufficient conditions for when the connection requirement is not satisfied. These are sufficient conditions for D's action, A, to not manifest as much insufficient regard as it would if D's knowledge were appropriately connected to A. This, as we'll see, 
is what enables the account to accommodate cases of latent knowledge, and thereby satisfy Desideratum 2 .

The first of these sufficient conditions for the connection requirement not being satisfied follows from prong (1). Specifically, the connection requirement remains unsatisfied if:

$\left(1^{*}\right) \mathrm{D}$ only acquired $\mathrm{K}$ after performing $\mathrm{A}$.

This is hardly surprising. We saw the importance of this rule in Part I. $^{113}$ More interestingly, in virtue of prong (2) the connection requirement would also not be satisfied if:

$\left(2^{*}\right) \mathrm{D}$ is not in conditions (cognitive, situational, etc.) where we would expect $\mathrm{K}$ to trigger an overriding motivating reason not to do A.

This sufficient condition might obtain, for example:

(i)because $\mathrm{D}$ is reasonably distracted or overwhelmed by the circumstances,

(ii)because $\mathrm{D}$ acquired $\mathrm{K}$ so long ago that he reasonably forgot it even if he would remember it if prompted (i.e. we cannot have expected a law-abiding person to recognize and guide his behavior in light of $\mathrm{K}$ ), or

(iii) because, although $\mathrm{D}$ has sufficient regard for others (i.e. has a sufficiently strong desire

for their good), D was in a state of shock that

prevented him from fully controlling his

conduct despite being conscious of his behavior at the time.

It is $\left(2^{*}\right)$ that explains why the connection requirement sometimes is not satisfied in cases of merely latent knowledge. Recall the case of Frank. The explanation for why the connection requirement was not satisfied there is that, given the emotional disturbance Frank experienced upon hearing that his family had been in the car accident, Frank did not seem to be in cognitive conditions where we would expect his knowledge of Bernie's fraud to trigger a motivating reason against authorizing the transfer to Bernie. It clearly provided him with a normative reason not to authorize the transfer, but in light of his disturbed emotional state, his knowledge cannot plausibly be expected to trigger a motivating reason to this effect (i.e. to make this normative reason a motivating reason of his). Accordingly, $\left(2^{*}\right)$ is satisfied, and

113. See supra notes $22-33$ and accompanying text. 
prong (2) of the connection requirement is not. This explains the intuition that Frank's knowledge was not sufficiently connected to his conduct to take him to be guilty of knowingly aiding and abetting Bernie's fraud.

Fortunately, for the present account, it does not entail that all cases of latent or not fully conscious knowledge fail to satisfy the connection requirement. Instead, the account clearly also allows that some nonoccurrent, non-conscious beliefs (ones you would be able to call to consciousness on reflection or if prompted) can still be sufficiently connected to your action to be the basis for holding you accountable for it as a full-fledged knowing action. For example, recall the Jackson court's dictum that "Jackson would be guilty of 'knowingly' failing to appear if he decided early on that he would not attend his scheduled court appearances, and he then dismissed the matter from his mind."114 In such a case, Jackson's knowledge of his obligation to appear in court would be latent. After all, we are supposing that he "dismissed it from his mind." Nonetheless, in the court's example, there are no disturbing factors that would prevent us from reasonably expecting Jackson's latent knowledge of his court date to provide an overriding motivating reason against failing to appear. Accordingly, my account correctly entails that in the court's example, Jackson's latent knowledge of his court date would be adequately connected to the actus reus of failing to appear, such that a conviction for the crime of knowingly failing to appear would be in order.

Thus, whether or not one's latent knowledge will be appropriately connected to the actus reus in a given case will depend heavily on whether one is in circumstances that make it reasonable to expect that one's latent knowledge should trigger an overriding motivating reason against performing the actus reus in question. (Note that the present account also has plausible implications about corporate cases that are analogous to latent knowledge, ${ }^{115}$ as well as deviant causation cases. ${ }^{116}$ )

114. Jackson v. State, 85 P.3d 1042, 1043 (Alaska Ct. App. 2004).

115. Recall the case in which a corporation is charged with making false statements to the US government, discussed supra, note 78. Employee Alice submitted the report without knowing it contained false statements. Employee Betty, who did not work on the report with Alice, happened to pick up a copy of the report and saw certain false statements in it, but did not recognize the significance of the statements or the report itself. The present account entails that the connection requirement is not satisfied here. After all, Betty worked on different matters from Alice and had no way of knowing the significance of the false statements or the intended uses of the report. Therefore, Betty was not in a position in which we would have expected her knowledge to trigger any motivating reasons-either on her part or on the part of any other corporate 
Before proceeding, let me address one potential source of confusion. Specifically, one might wonder what happens if it is already the case that-even without the relevant knowledge-you ought to have an overriding motivating reason against doing the actus reus, i.e. one with sufficient strength to override any motivation you might feel in favor of doing it. For example, even if you do not have any reason to think someone is in the building you intend to burn down, it still might be the case that you ought to have a decisive motivating reason not to burn it down. After all, it does not belong to you, and you should have a desire not to damage the property interests of others (or something along these lines).

This is not a problem for the account defended here, however. After all, the knowledge that someone is inside the building should provide you with an additional motivating reason not to burn down the building. If the motivating reasons you should have had not to burn

employee-against submitting the report to the government. In Betty's situation, she could not have been expected to be motivated by her knowledge to tell Alice or any of her other coworkers about her discovery of the false statements, or in any other way to give other employees in the corporation any motivating reasons not to submit the report in its current condition. Accordingly, the normative inquiry recommended by my account yields the result that the connection requirement is not satisfied as between Betty's knowledge and the submission of the report.

By contrast, my account yields the opposite result in the variation of the corporate case where Betty* is Alice's direct subordinate and both were involved in the preparation of the report. It can reasonably be expected that practices will be in place within the corporation to enable pertinent information to rise through the ranks, such that those who carry out key actions-like Alice in submitting of the report the government-have the relevant facts before them. Accordingly, Betty*'s knowledge of the falsehoods in the report should have given rise to a motivating reason on the part of Alice to refrain from the criminal act in this case-i.e. a reason not to submit the report in its current condition. Thus, this would be another case of causation by lack of contrary reasons. One part of the corporate person (Betty*) possessed the relevant knowledge, and another part of the corporate person (Alice) failed to be responsive to that knowledge despite being in circumstances where it is fair to expect that this knowledge in question trigger an appropriate response. Accordingly, on the current account, the connection requirement would indeed be satisfied.

116. The present account says the connection requirement is satisfied for the case of deviant causation discussed supra, note 54. In that case, Fred's knowledge that a person is in the building should indeed have given him overriding motivation not to set the building on fire. Because he was not thus motivated, despite being in circumstances where such motivation can reasonably be expected, the connection requirement is satisfied as between his knowledge and his actions. 
down the building in the first place were not sufficient to get you to abstain from doing so, then clearly the knowledge that someone is inside the building should tip the scales in favor of not burning it down. If you proceed to burn down the building despite your knowledge that someone is inside, this reveals an even greater degree of insufficient regard for others than would be manifested in the absence of such knowledge. Accordingly, the account defended here remains plausible despite this complication. $^{117}$

117. An additional question my account might raise concerns the muchdiscussed, tragic cases in which someone purely by accident leaves a pet (or worse a child) to languish in the car in extreme heat or cold, only to remember too late. It is key to these cases that no obvious animus was involved; the pet or child simply slipped the actor's mind. See, e.g., SHER, supra note 44, at 24; Holly Smith, Non-Tracing Cases of Culpable Ignorance, 5 CRIM. L. \& PHIL. $115,115-16(2011)$. These cases are typically treated as cases of negligence. Id. Nevertheless, my account might seem to entail that the actors in these cases not only acted knowingly, but indeed that the connection requirement between the relevant piece of knowledge and conduct was satisfied. Perhaps one finds this implausible.

This objection admits of two replies. First, many of these cases are likely to involve genuine forgetting, as opposed to the latent possession of actual knowledge. That is, the actor in question (depending on the facts of the case) is likely to not be aptly described as possessing genuine (albeit latent) knowledge of the pet or child in the car; rather, the more apt description is likely to be that the actor completely forgot about the pet or child, and no longer had access to the pertinent information. If the actor genuinely forgot, then she would not be plausibly characterized as latently knowing. But my account would only entail that the connection requirement is satisfied if the actor really did possess genuine knowledge of the child or the pet at the relevant time (even if just latently). Accordingly, my account will not have the problematic implication that the connection requirement is satisfied in very many real-life versions of these cases.

To this, one might respond that there could be some cases in which one really did latently possess the relevant knowledge of the pet or child in the car at the time. Thus, a second answer to the present objection is that in such cases, the correct result is that the connection requirement really is satisfied. That is, in cases where it is undisputed that the actor really did possess latent knowledge, but nonetheless found herself in circumstances where we can expect this knowledge to provide an overriding motivating reason against leaving the pet or child in the car but it didn't, then the actor really did knowingly leave the pet or child in the car. If there is no reasonable excuse or explanation for why the actor's knowledge of the pet or child in the car failed to trigger a motivating reason against leaving the pet or child where it was, then this knowledge plausibly was connected in the required way to the actor's conduct. Accordingly, conviction of a knowledge crime seems appropriate-even if the 


\section{B. Extending the Account to Recklessness}

An additional benefit of the account I have developed here is the ease with which it can be extended to recklessness. After all, whereas criminal knowledge amounts to practical certainty that the inculpatory proposition is true, recklessness can be understood as the awareness that there exists a substantial chance that it is (or will be) true. Accordingly, we get the following:

Connection Requirement for Recklessness: D's belief, B, that there is a substantial risk that the relevant inculpatory proposition $\mathrm{p}$ is true (where p could be, e.g., that one's conduct will cause harm) is appropriately connected to D's performance of the actus reus, A, if and only if:

(1) D possesses $B$ at least latently during the relevant part of his performance of $A$,

(2) while A'ing (or the relevant part of it) D is in conditions (cognitive, situational, etc.) where we would expect $\mathrm{B}$ to give a law-abiding person in D's situation a decisive (overriding) motivating reason not to do A (i.e. to do something besides $\mathrm{A}$ that would not risk imposing the relevant harm associated with p), and

(3) $\mathrm{B}$ did not actually give $\mathrm{D}$ a motivating reason against $\mathrm{A}$ of sufficient strength to get him to refrain from doing A (i.e. he did A anyway).

One might be puzzled over the fact that the above account does not explicitly mention that the defendant must be aware not only that the relevant risk is substantial, but also that it is unjustified. ${ }^{118}$ Nonetheless, this requirement that one be aware of an unjustified risk can be understood in terms of the relevant excusing conditions mentioned in prong (2). After all, if D really does (reasonably) think he has justifying reasons for imposing the risk in question, then $\mathrm{D}$ will not be in conditions that would make us expect D's awareness of the risk to trigger an overriding motivating reason against doing A. Accordingly, it follows from my account that the connection requirement will be satisfied only if the defendant believes that the risk in question is both substantial and unjustified.

case also is likely involve mitigating circumstances that a judge should take into consideration when sentencing the defendant.

118. Cf. supra note 59 (noting that the MPC defines recklessness as acting despite being aware of a substantial and unjustified risk). 
But notice that the same result does not necessarily arise in the case of knowledge. In principle, it could have, of course. That is, in principle the law might have been such that one is only guilty of a knowledge crime provided one does the actus reus with knowledge of the inculpatory proposition and one is not aware of any circumstances that would justify the truth of that proposition. However, as Simons himself observes in another paper, ${ }^{119}$ this is not what the law actually requires. In reality, the law takes it that except for the few formally recognized affirmative defenses, there are no conditions that justify knowing criminal conduct. ${ }^{120}$ In this way, knowledge crimes differ from recklessness crimes. My account helps explain this difference.

\section{Concluding Remarks}

The account of the connection requirement for knowledge and recklessness defended in this Article has significant explanatory power. In particular, it provides a normative test for whether a particular piece of knowledge, or the awareness of a particular substantial and unjustifiable risk, is appropriately connected to the actus reus to ground the corresponding culpability attributions and criminal sanctions. This test is not counterfactual in nature, and thus does not risk attributing culpability to defendants on the basis of how they would behave in non-actual circumstances (i.e. how they merely were willing to act). Rather, my test looks at the actual circumstances of the defendant's conduct, and asks whether the defendant's knowledge of some inculpatory fact, or awareness of a given risk, can be expected to trigger an overriding motivating reason not to perform the actus reus of the crime in question. If this can be expected of the defendant, and if he proceeds to perform the actus reus anyway, this reveals that the motivating reason we expected him to have was not triggered because he possessed an insufficient amount of regard for the interests of others. This, then, explains the culpability of the defendant's knowing or reckless misconduct.

Furthermore, this approach can be applied not only to knowledge or risk-awareness that is fully conscious, but also to cases of latent or not fully conscious knowledge or risk-awareness. In those cases, too, we can

119. Ken Simons, Rethinking Mental States, 72 B.U. L. REV. 463, 474-75 (1992) ("Once an actor perceives a 'highly probable' risk of physical harm, she is prima facie liable for assault or murder. She must fit within a limited number of defenses in order to avoid conviction. But an actor who perceives only a "substantial" risk is not liable unless her conduct both is unjustifiable and is a 'gross deviation' from social norms, considering all of the circumstances."). 120. Id. 
profitably ask whether the defendant's latent knowledge, or latent awareness of the risk, should have triggered an overriding motivating reason (or at least an additional one) to abstain from the actus reus. If it should have and he did the actus reus, then the connection requirement will be satisfied. However, if he is not in conditions where we would expect his latent knowledge or risk-awareness to trigger such a motivating reason, then the requirement will not be satisfied. Accordingly, this Article provides a principled way to separate the cases of latent knowledge or risk-awareness in which the connection requirement is satisfied from those cases in which it is not. 
